\title{
HISTORY OF THE PRODUCTION COMPLEX: THE METHODS OF SITE SELECTION
}

September 1987

\section{DISCLAIMER} This report was prepared as an account of work sponsored by an agency of the United States
Government. Neither the United States Government nor any agency thereof, nor any of the
employees, makes any warranty, bility for the accus warranty, express or implied, or assumes any thereof, nor any of their process disclosed acy, completeness, or usefulness of any informy legal liability or responsience herein to any represents that its use would not infringermation, apparatus, product, or manufacturer any specific commercial product, process, or service privately owned rights. Refermendation, or faring does not necessarily constitute or ice by trade name, trademark, and opinions of auth by the United States Government or imply its endorsement, recomUnited States United States Government or any agency thereof.

Prepared by:

History Associates Incorporated Rockville, Maryland 20852

Prepared for:

U.S. Department of Energy

Assistant Secretary for Defense Programs Office of Nuclear Materials

Under Contract No. DE-AC08-87NV10594

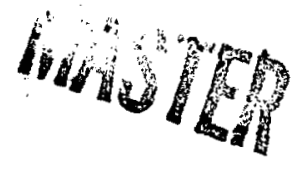

This document is PUBLICLY RELEASABLE

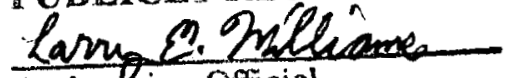
Authorlzing Official Date: $02 / 15 / 2006$ 


\section{DISCLAIMER}

This report was prepared as an account of work sponsored by an agency of the United States Government. Neither the United States Government nor any agency Thereof, nor any of their employees, makes any warranty, express or implied, or assumes any legal liability or responsibility for the accuracy, completeness, or usefulness of any information, apparatus, product, or process disclosed, or represents that its use would not infringe privately owned rights. Reference herein to any specific commercial product, process, or service by trade name, trademark, manufacturer, or otherwise does not necessarily constitute or imply its endorsement, recommendation, or favoring by the United States Government or any agency thereof. The views and opinions of authors expressed herein do not necessarily state or reflect those of the United States Government or any agency thereof. 


\section{DISCLAIMER}

Portions of this document may be illegible in electronic image products. Images are produced from the best available original document. 
TABLE OF CONTENTS

Page

EXECUTIVE SUMMARY $\ldots \ldots \ldots \ldots \ldots \ldots \ldots \ldots \ldots \ldots \ldots \ldots \ldots \ldots$

INTRODUCTION $\ldots \ldots \ldots \ldots \ldots \ldots \ldots \ldots \ldots \ldots \ldots \ldots \ldots \ldots \ldots \ldots \ldots$

I. PROLOGUE: THE SELECTION OF THE OAK RIDGE SITE .... 3

SOURCES FOR CHAPTER I ................... 6

II. THE REACTOR COMPLEXES .................. 7

Hanford site $-1942 \ldots \ldots \ldots \ldots \ldots \ldots \ldots \ldots \ldots$. 7

The Proposed Duplication of Hanford Facilities and

the Selection of the Reactor Proving Ground Site

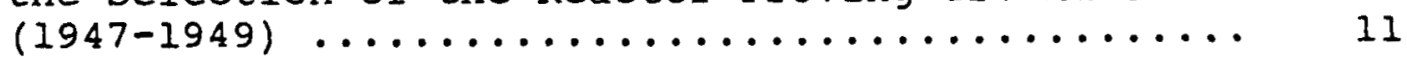

The Proposed "Hanford Duplication" ............. 11

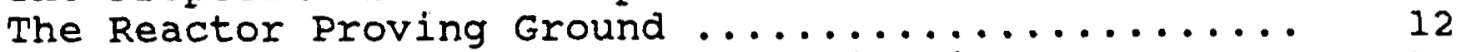

Starting over with Appropriate criteria ......... 14

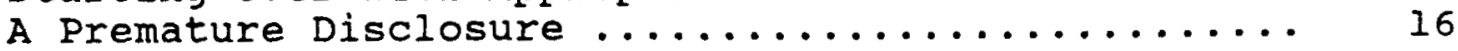

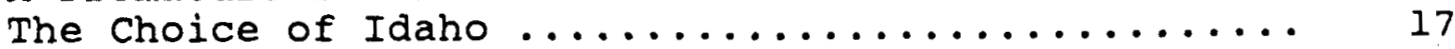

The Savannah River site Selection (1950) ........ 20

The survey Begins ....................... 24

The Process Withstands Incremental Adjustments of

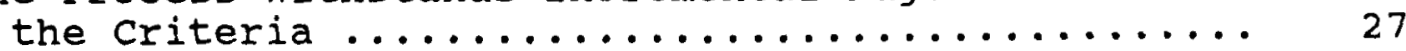

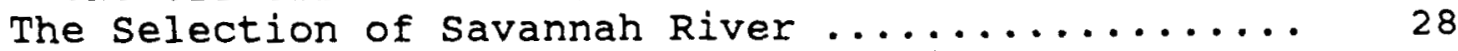

The process Hits a snag--The Evacuation of a Town 29

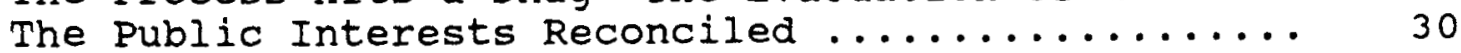

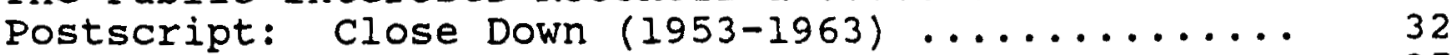

SOURCES FOR CHAPTER II .................. 35

III. GASEOUS DIFFUSION PLANTS: PADUCAH AND PORTSMOUTH 38

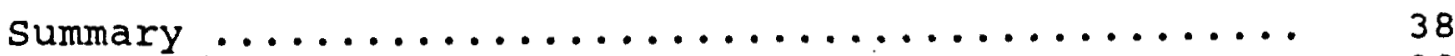

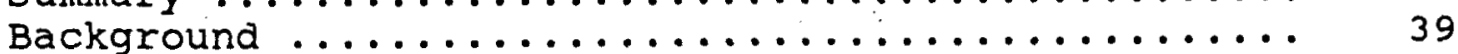

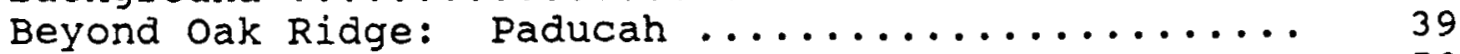

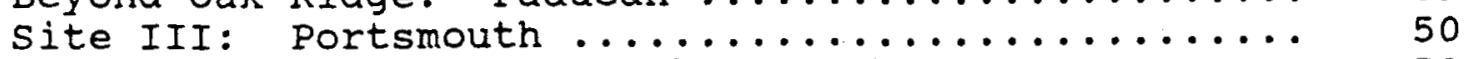

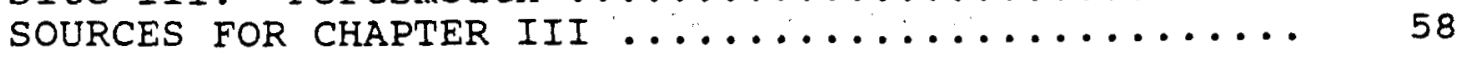


Page

IV. FABRICATION, ASSEMBLY, AND OTHER FACILITIES ......

1. The Fernald Feed Materials production center

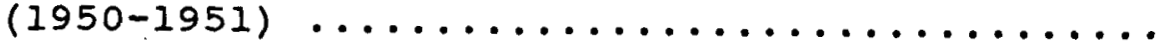

2. HE Fabrication Facilities: PANTEX and spoon

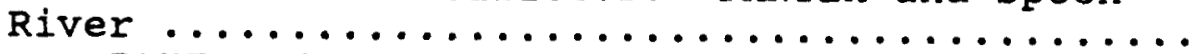

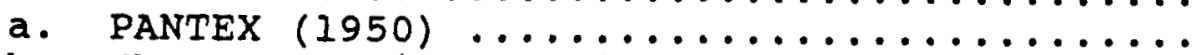

b. The spoon River Project $(1951-1953) \ldots . .$.

3. Rocky Flats Fabrication Facility (1951) ......

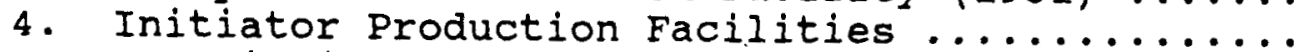

a. Miamisburg (Unit VI - Marion), ohio ........

b. The Pinelias Peninsula Plant (1955-1956) ..

SOURCES FOR CHAPTER IV ..................

\section{APPENDIX A - DATA ABOUT SELECTED PRODUCTION FACIIITY SITES}

$y-12$, oak Ridge .....................

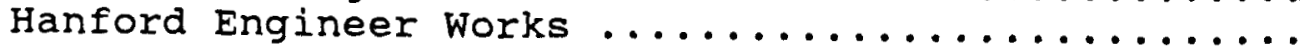

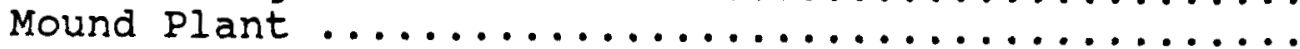

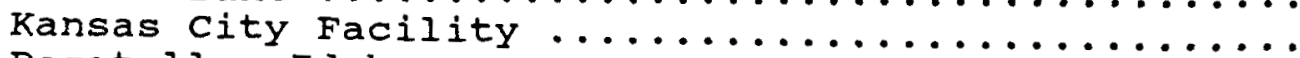

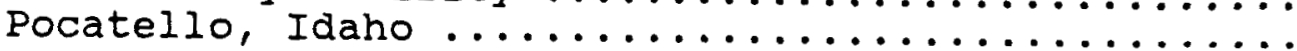

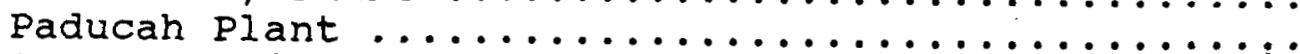

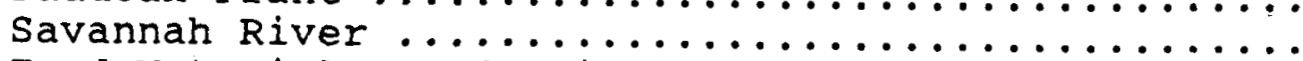

Feed Materials Production Center, Fernald, ohio...

PANTEX

Rocky Flats, colorado

Portsmouth

Pinellas Peninsula plant

APPENDIX B

Idaho Reactor Testing station (1949) - Facsimile of the Engineering Division's Summary "Comparison

of the Ft. Peck and Pocatello sites"

APPENDIX C - SAVANNAH RIVER SITE SELECTION, 1950

Defense Department Map of Preferred Defense Zones, with the four final candidate sites indicated by black circles

APPENDIX D - SAVANNAH RIVER SITE SELECTION, 1950

Schematic Diagram of Preliminary Technical, safety, and Population criteria 
EXECUTIVE SUMMARY

Experience taught the Atomic Energy Commission how to select the best possible sites for its production facilities. AEC officials learned from the precedents set by the wartime Manhattan Project and from their own mistakes in the immediate postwar years. By the 1950-1951 expansion programs, they had become proficient enough to manage several complicated siting projects simultaneously and to consummate them successfully in a short time. Later, when they had to consolidate excess plant capacity in late 1952, they developed a similarly effective method for deciding how to close facilities.

General Trends in Siting Policy, 1942-1964

The Manhattan Project siting planners found it expedient to locate production facilities in remote reservations, partly for secrecy and military security, and partly out of concern for public safety in the event of a catastrophic reactor accident. In choosing isolated areas, however, the Manhattan Project officers dispensed with the usual practice of locating a large industrial facility near adequate housing, services, construction labor, and skilled work force. Instead, the Manhattan Project had to build and administer whole new communities and to draw masses of people from other places to work at the sites. The AEC inherited these problems after 1947. By 1950 the AEC decided that new sites must have a sufficient number of existing 
communities in the vicinity so that it would never again be necessary to administer government towns like oak Ridge and Richland.

The Manhattan Project siting planners also found it expedient to locate production facilities where the needed resources--water, electric power, labor, fuels, and construction materials--could be provided most economically and dependably. The War Department's general requirement of defensibility excluded only the coasts and a narrow strip of land along the Canadian and Mexican borders. Hanford, Washington, a perfect natural site for production reactors, was far enough inland to satisfy the War Department. After World War II, however, the new threat of soviet long-range bombing and airborne invasion led the Defense Department to recommend that the AEC not site additional production facilities in the Pacific Northwest. As the potential range of soviet aircraft increased, the vulnerable area grew to include the west and the northern tier of states as well, shrinking the area available for safe siting. BY 1950 the AEC staff decided to limit their site surveys to the south and the Ohio River region.

The Manhattan Project planners had preferred to group as many production facilities as possible on the reservations at oak Ridge and Hanford for the sake of secrecy and administrative control. After the war, however, the threat of a total incapacitation of Hanford facilities from soviet bombing led the AEC to make plans to "duplicate" Hanford elsewhere and in general 
to disperse facilities away from the original reservations. once dispersal became desirable for strategic reasons, the AEC had to learn how to define appropriate site criteria for different types of production facilities. The first attempts in 1947-1949 were awkward, and the final decisions to site the "Unit VI" initiator facility at Marion, ohio, and the experimental reactor proving grounds at Pocatello, Idaho, each took a year. Thereafter, the AEC became proficient enough to site a diverse group of facilities in a matter of months or weeks, often simultaneously, which contributed to the overall efficiency of the expansion of $1950-1952$.

Once expansion was found to have exceeded the Defense Department's requirements by mid-1952, the AEC confronted the necessity of consolidating production at its many sites in a manner that would balance several desired goals: cost efficiency, reserve capacity for future emergencies, and minimizing the negative social consequences of closing down facilities. The first such decision was the cancellation of Project PLUM, the third HE fabrication facility planned in the 1951 expansion program. The criteria for that decision were economic and strategic in nature and did not include consideration of the qualities of the site which had been selected for PLUM at spoon River, Illinois. A second consolidation occurred in 1953 when the AEC decided to maintain one of the three plutonium fabrication facilities in a "standby" condition. The new facility at the savannah River reactor 
complex was chosen on the basis of a strategic criterion to spread the fabrication work over as many dispersed sites as possible. The same policy criterion was applied in the next wave of consolidation, in 1963-1964, that introduced the schedule of alternating reactor shutdowns at Hanford and Savannah River.

Specific Problems and Solutions: Reactor complexes

The Manhattan Project officers initially determined the requirements for a production reactor complex in meetings with reactor engineers and then turned to their fellow officers in the U.S. Army Corps of Engineers to recommend several potentially satisfactory sites. The criteria they used were rough, since the technology was new, but fortunately the corps had officers familiar enough with the resources and topography of the country to make the recommendation of Hanford an easy matter. Fortunately, too, Hanford was such an outstandingly satisfactory location for the criteria that the inspection of several other sites in the west did not delay its selection for more than a few days.

The AEC relied on the corps of Engineers in 1948 to recommend potential sites both for the plan to "duplicate" Hanford facilities elsewhere and for the proposed reactor testing station. Unfortunately, the AEC could not provide the corps with specific requirements for experimental reactors planned for the proposed testing station, so the corps recommended a list of sites that satisfied the older Hanford criteria for production 
reactors, but without providing detailed data on the sites. Consequently, the AEC remained ignorant about the real advantages and liabilities of the locations it was considering for the two facilities. This mudale required months to straighten out, but the AEC learned from the experience and was able to choose the next site, Savannah River in 1950, with a minimum of difficulty. The selection of Idaho for the Reactor Testing station also taught the AEC to conduct future searches with more "political" circumspection. Before the decision was made in favor of an Idaho site, several high AEC officials prematurely revealed to a senator that another site in a different state would probably be chosen. When the AEC announced Idaho instead, there was a congressional hearing to determine why. All of the haphazard moves that the AEC staff had made during the process came out in the questioning. For the next reactor siting project, savannah River, the AEC insured itself against a repetition of the embarrassment by leaving the ranking of potential sites in the hands of the engineering contractor, Dupont, and by appointing an independent review committee to examine the contractor's procedures and its top five candidate sites, all before the AEC itself would formally receive the company's recommendation and vote to approve it.

\section{Gaseous Diffusion Plants}

The rationale for the decision to locate additional gaseous diffusion complexes at sites other than oak Ridge was the need 
for increased production and "security through dispersion." Two major considerations shaped the primary criteria: (1) secure production capacity demanded locations within the "strategically safe" zone; and (2) the massive amounts of electricity consumed in the gaseous diffusion process (85-90 percent of plant operating costs) dictated the choice of sites with readily available, low-cost power. The korean war imposed rigid time constraints on the selection effort, especially in the 1950 selection, which was confined to sites already owned by the government. After the acquisition of the Kentucky ordnance Works at Paducah in November 1950, the Commission experienced some minor difficulties in settling on a power supply contractor. Chronic labor strikes and a severe housing shortage were more serious problems which contributed to construction delays at Paducah.

With the construction of additional capacity under way, the 1952 site selection was a more methodical, cautious exercise which reflected the lessons learned at Paducah. Factors beyond the commission's control, however, dictated the ultimate choice. Politics were a major consideration in 1952. Vehement opposition to an AEC facility at Louisville and the refusal of Cincinnati craft unions to accept the AEC's contract proposals were critical factors in selecting Portsmouth, the Commission's third choice. 
Fabrication, Assembly, and other Facilities

Historically, the siting of fabrication facilities and other auxiliary elements of the production system in dispersed locations of the major complexes had been far less difficult than the siting of reactors or gaseous diffusion plants. In general, the technical requirements for fabrication facilities alone are considerably less demanding, particularly in regard to isolation for the safety of surrounding communities. The policy of strategic dispersion meant they would not be added to existing reservations such as oak Ridge or Hanford but sited elsewhere according to criteria appropriate for their operation.

The experience accumulated in siting the reactors and gaseous diffusion plants "carried over" in siting the large number of auxiliary facilities the AEC built during the 1950-1951 expansion. All were to be located in geographical areas remote from Soviet airfields as defined by the Defense Department. The auxiliary facilities had to be near existing communities of sufficient size to provide the skilled technical and construction workers needed to build and operate the facility. In setting the latter requirements, the AEC sought to avoid both the construction of new towns as had been done at Los Alamos and Hanford and the excessive demand and resulting problems experienced at Paducah and Savannah River in early 1951. 


\section{HISTORY OF THE PRODUCTION COMPLEX:}

THE METHODS OF SITE SELECTION

\section{INTRODUCTION}

Most of the weapons production complex that the Department of Energy inherited was built in a comparatively short time--in 1942-1944 and in 1947-1953. One consequence of this was that the people involved gained experience as one spurt of expansion followed another, often within a few months. They developed what we would nowadays call a rich "corporate memory." More than thirty years have passed since the last spurt during the Korean War, and the generation that had learned from experience how to site a reactor complex is now gone. Fortunately, they recorded their efforts in detail. This report summarizes what they learned about siting reactors, gaseous diffusion plants, feed processing, fabrication, and initiator production facilities.

It is evident from the way the AEC records were arranged that they were intended for use as a planning tool in the future. In preparation for each major decision, a staff paper was drafted to recapitulate the background of the issue and remind the decision-makers how policy had evolved from similar cases in the past and what mistakes were made.

This study is written in the form of a narrative that traces the progress made over the years in designing siting criteria for new facilities. It points out the decisive criteria in the more important episodes, but most of the data about the successful candidate-locations are not in the text itself but in Appendix A. 
Throughout the following narrative the military terms "strategic," "operational," and "tactical" are often used to denote the scale of the considerations involved in determining criteria. "strategic" includes the broadest considerations of national military and economic potential, the defense of the proposed facility from enemy attack, and its relation to the other facilities, existing or proposed, in the production system. Below this is the level of "operational" considerations, which include the features of area terrain, population, and resources which must fit the specific requirements of the production facility. Finally, the "tactical" considerations of choosing a particular site within a general area include such considerations as local housing availability and proximity to important transportation facilities, which were often made the basis of a "secondary" set of criteria to be applied in the final stage of decision-making. 


\section{PROLOGUE: THE SELECTION OF THE OAK RIDGE SITE}

General Leslie $R$. Groves selected the first large reservation for producing nuclear materials at oak Ridge, Tennessee, in 1942. The decision was his first act after being sworn in as head of the Manhattan Project. Groves acted quickly because he was impatient with his predecessor's more deliberate handling of the site acquisition while the project was under the Office of Scientific Research and Development (OSRD). The OSRD had already picked out an area near Knoxville, Tennessee, by April 1942, on the assumption that electrical power would be the chief requirement of whatever production facilities would be built. Wartime pressure on the country's electrical power resources made this a strategic criterion, and TVA officials recommended the Knoxville site. All the other criteria were developed later, at a meeting of the OSRD S-I Executive committee on June 25. There it was agreed to follow the war Department's policy of locating new munitions plants between the Appalachians and the Rockies, safely out of range of enemy carrier-based aircraft, and no closer than 200 miles to the canadian or Mexican borders. For secrecy, the OSRD planners decided to place all of the production units on one site. Such concentration would also facilitate rapid construction and simplify control over the builders. Even though the OSRD planners did not yet know the nature of the production processes that would be sited there, it was possible to agree on some preliminary criteria based on 
general engineering practice and a rough assessment of the additional requirements posed by atomic production facilities. The site was to be generally isolated from population centers, and on terrain broken up by ridges so that an explosion at one plant would not damage the others; it had to be near a river with a flow of "hundreds of thousands of gallons a minute" and a dependable power supply of $150,000 \mathrm{kw}$ "by the end of 1943." The OSRD estimated that a reservation of 200 square miles would be needed to locate safely all of the plants for the processes still under consideration.

Later, when OSRD officers brought the construction engineering firm of stone and Webster into the project, the company added a number of other criteria: the slopes of the ridges required for security and safety should not be so steep that they would make construction difficult. The ground should be solid enough to bear a very heavy building but not so rocky that excavation would be too time-consuming. Adding these engineering criteria complicated finding a particular site in the area which the OSRD had chosen. After a three-day survey around Knoxville, OSRD and company representatives found only one site on the clinch River approximately satisfying their requirements-the site that ultimately became the Oak Ridge complex.

Still, Colonel James c. Marshall, the Army officer responsible to OSRD, hesitated to acquire the site. The main reason was that he was reluctant to spend the approximately $\$ 4.25$ million necessary to purchase 200 square miles, build a 
highway detour, and evict 400 poor farm families until he was certain that the planned plutonium pile would really require as much evacuated space around it--between 2 and 4 miles--as the OSRD had assumed in setting the initial criteria. If it were not for the plutonium pile, the 200 square mile requirement could be cut in half.

Marshall's delay exasperated Groves. A bad decision, he said, was better than none at all. Thus, when Groves was put in charge of the new Manhattan Project on September 23, 1942, the first thing he did was to take an overnight train to knoxville and, in a few hours of driving around the area, picked the oak Ridge site. 
AEC 1140. A History of the Expansion of AEC production Facilities, August 19, 1963, DOE Archives.

Groves, Leslie R. Now It Can Be Told: The story of the Manhattan Project. New York: Harper \& Brothers, 1962.

Memoirs of the military head of the Manhattan Project.

Hewlett, Richard G., and Anderson, Oscar E., Jr. A History of the United States Atomic Energy Commission. Vol. I: The New World, 1939-1946. Washington, D.C.: U.S. Atomic Energy Commission, 1972 .

Jones, Vincent c. Manhattan: The Army and the Atomic Bomb. Special studies. Washington, D.C.: U.S. Army Center of Military History, 1985.

Manhattan District History. Book I, General: Vol. 12, Clinton Engineer works, Central Facilities. Manuscript, 1948, DOE Archives.

Contains detailed descriptive history of factors considered in selecting oak Ridge.

U.S. Congress. Senate. Report to the Congress by the United States Atomic Energy Commission. S. Doc. 8, 80 th Cong., lst sess., January 31, 1947 . 


\section{THE REACTOR COMPLEXES}

Hanford Site -1942

The original idea of siting the plutonium production pile at Oak Ridge with a two to four mile safety zone around it did not satisfy the apprehensions of the DuPont Company, the contractor General Groves engaged to build and operate it. DuPont's engineers were new to every aspect of atomic energy. They worried that "premature criticality" of plutonium would cause an explosion, devastating the reservation and sending a lethal cloud over Knoxville to the east. Groves was less concerned about the safety of Knoxville than about the war industries in the TVA region. Now that construction teams had begun work on several processing plants at Oak Ridge, he was reluctant to risk slowing the project to acquire the additional land for a pile and a big safety area around it. Besides, building and operating the pile would drain the construction labor resources and electric power capacity needed for other plants. So he agreed with DuPont to find a new site.

The criteria that Dupont and Groves's deputies developed on December 14, 1942, represent the first systematic attempt to match technical reactor requirements to engineering and safety considerations.

The "operational" criteria developed by reactor engineers at the Metallurgical Laboratory in Chicago were the main considerations. They recommended taking enough land for 6 
reactor areas, separated from each other by not less than a mile, and 4 "secondary areas" for the even more hazardous separation plants, to be spaced not less than 4 miles from each other and from the reactors. Six reactor areas would be more than were needed for the number of reactors then planned (2). This decision made good sense from the strategic standpoint, but it complicated the operational task of finding a site isolated enough where all 6 reactors could be operated at full power without endangering the adjoining population. The reactor engineers recommended evacuating a 10-mile wide "exclusion area" around the "manufacturing area." A lo-mile complex would require an "exclusion area" of about 700 square miles. And beyond it the engineers suggested prohibiting residential occupancy in an area of 44 by 48 miles-more than 2,100 square miles. There could be no major public roads or railroads within the 700-square-mile reservation. There could be no towns with more than 1,000 population closer than 20 miles.

Few such empty places in the united States existed--few, that is, which could also satisfy the reactor engineers' parallel requirements for water and electric power. These called for a river of "relatively pure" and "reasonably low temperature" water flowing through the reservation at a volume of "not less than 25,000 galions per minute." There also had to be at least $100,000 \mathrm{kw}$ of electrical power capacity in the area to pump the coolant water from the river to the reactors, to power all of the machinery at the facilities, and to provide household current for 
the construction camp and the new town that would be built. Moreover, due to the wartime scarcity of metal, the site should not be so far from the power source that it would be necessary to build long transmission lines.

In case more than one general area was found that happened to satisfy the prime criteria, the Dupont construction engineers recommended a supplementary list of "secondary considerations" to make the final choice: solid ground for heavy structures, relatively level land, and a mild climate for easy, year-round construction.

Wartime economic considerations shaped a number of other secondary criteria. Arable land should not be taken, if possible. Local supplies of gravel should be sufficient for the vast amount of concrete that would be mixed. Local, or at any rate regional, supplies of coal and oil should be sufficient for the emergency generators' stockpiles-the farther away these resources, the more expensive it would be to ship them to the site.

There was one more "secondary criterion": the site should not displace "any more inhabitants than necessary." The isolation that was required for safety, in other words, should not be "created" by evacuating masses of people from an area.

Having reached agreement on these criteria in the short space of a day, the Manhattan Project officers then turned to the corps of Engineers to help find a site. Groves told his deputy, colonel Franklin T. Matthias, to consult the officers who best 
knew the country's current power availability. They advised that the Pacific Northwest, and particularly the Bonneville power Authority in washington, had enough unused capacity that would be available year round, without having to install additional generating equipment. This feature eliminated the need for Iarge emergency stockpiles of coal or oil. The Pacific Southwest was a good second choice, but the hydroelectric system of the colorado River was not dependable from year to year and extra generators and fuel reserves would be necessary. The TVA area was considered briefly, but its capacity would be taxed by the growing Oak Ridge requirements.

When the Manhattan Project officers flew to the Pacific Northwest on December 16, they already had a prime candidate area in mind: Hanford-White Bluffs. Nevertheless, they sent three men to the District Engineer's offices in seattle, san Francisco, Sacramento, and Los Angeles to consider the possible use of other sites. In the last two weeks of December the visitors inspected two sites near the Grand coulee dam; another in the Deschutes River Valley area; two sites in southern california on the colorado River system; and Hanford-White Bluffs. They chose Hanford. The alternates were not so "clearly desirable": Adin, in northern California near Mt. Shasta', was too close to the ocean to satisfy the war Department's policy regarding defensibility. The third-ranking candidate area, near Needles in southern California, was subject to the fluctuating hydroelectric 
capacity of the colorado River that the corps of Engineers power experts had warned about.

The Proposed Duplication of Hanford Facilities and the selection of the Reactor Proving Ground site (1947-1949)

The Atomic Energy Commission "inherited" the siting criteria developed by the Manhattan Project. That is, the commission staff turned to them when, in November 1947 , it was directed to consider the pros and cons of building additional reactors at a new reservation at a site other than Hanford. The staff investigation reached its mature stage in the spring of 1948, at the time that the commission was also starting to consider siting its experimental reactors at a remote proving ground. The staff subsequently confused these two projects in their planning, an error that caused a year's delay and an embarrassing congressional hearing after the proving ground site was finally chosen in 1949. Nevertheless, the lessons they learned from the experience were useful in all of the commission's later siting efforts.

The Proposed "Hanford Duplication"

In July 1947 the AEC authorized the General Electric Company to construct two new plutonium production reactors. The original intention was to place them at Hanford, but a U.S. Army study questioning the defensibility of that area appeared in the fall of that year, prompting the commission to think about locating them elsewhere. The entire Pacific Northwest was now 
theoretically vulnerable to soviet long-range bombing, so the search would have to exclude that excellent source of potential sites, the columbia River Basin. The cost estimates for duplicating all of the facilities were found to be too high (\$270 milizion) to warrant purchasing such strategic insurance. Moreover, the splitting-up of the General Electric operating teams was judged to be too potentially disruptive of production. The AEC shelved the idea after reading the Production Division's staff paper.

The onset of the cold war in early 1948 revived the idea. The Production Division staff undertook a new study of the costs and advanced to the stage of considering--on paper only--a list of ten potential areas for locating the new complex. The list was considered appropriate for a large production reactor complex, with isolation criterion now derived by a formula of the new Reactor safeguard Committee: the radius of the totally evacuated "exclusion zone" was to be directly proportional to the thermal power output of the reactors $(r=.01,(\overline{\mathrm{kW}})$.

\section{The Reactor Proving Ground}

This formula was in fact devised for siting the commission's planned series of experimental reactors. The commission and its Reactor safeguard committee had approved the siting of a large experimental reactor at west Milton, New York, in late 1947, but everyone was concerned that it might not be operable at the power level necessary for its research program; it would be bound by 
the safety formula to curtail its operations because the city of Schenectady lay at the edge of the calculated safety zone. The next experimental reactors would be even more powerful. In early 1948 the High Flux Pile under development at the Argonne National Laboratory came up for siting. The AEC General Advisory Committee recommended establishing a remote proving ground for it and subsequent reactors which would be "even more objectionable from the safety point of view." In May the commission's Engineering Division staff, lacking precise knowledge of the operating characteristics of the reactors Argonne was considering, yet pressed to find a site for them, decided to begin their search using the "Hanford duplication" criteria which had been developed for production reactors with known operating characteristics, acting on the assumption that they would be comparably powerful. The hapless Engineering Division also "borrowed" the list of ten sites which were currently under consideration for the "duplicate Hanford." Fort Peck, Montana, headed this list.

In July, meanwhile, the Berlin Blockade crisis led the AEC to reconsider the duplication of Hanford one more time. The Production Division gave the commissioners another negative recommendation. The staff argued that the loss of plutonium production if Hanford was incapacitated could be made up by increased U-235 production elsewhere, and meanwhile there was a stockpile of plutonium at Los Alamos sufficient for the interim fabrication of weapons. The only element which could not be 
stockpiled, the polonium isotope for initiators, "Postum," could be produced in sufficient quantity in the research reactors at Brookhaven and Oak Ridge and in the High Flux Pile. To build a duplicate Hanford would now cost $\$ 430$ million, the production Division claimed. That estimate might be reduced by siting the new production reactors at the same place where the experimental reactors would be built, but even that was not necessary, the staff said; better not build the new reactors at all, and make the experimental reactors a polonium reserve. The AEC followed this recommendation, despite the dissent of commissioner Robert F. Bacher and Director of Research James B. Fisk, who argued against confusing the experimental reactor project by assigning any military production to the proving grounds. Among other things, military assignment would mean burdening the siting of the proving grounds with the geographical constraints of national defense, excluding areas of the country which might have been considered for a nonmilitary experimental "reactor farm."

\section{Starting Over With Appropriate Criteria}

After the AEC decided to drop the "Hanford duplication" scheme on August 5, 1948, the search for a reactor proving ground site was restarted with the intention of basing it on criteria specifically designed for the experimental reactors. Unfortunately, the staff still lacked most of the information it needed, both about the reactors that were planned and about the sites that were being recommended by the corps of Engineers on 
the basis of the old, preliminary criteria for production reactors which the commission staff had earlier given them. As time was now pressing, the staff directors made an expedient decision on october 18 to restrict their attention to the three most promising sites on the list in hand: Fort Peck, Montana; Oahe, South Dakota; and Wilmington, North Carolina. More precise information about these sites was requested from the corps and the U.S. Geologic survey. As it turned out, these ended in a blind alley. Fort Peck and oahe would ultimately fail to satisfy a concern that started to grow in the minds of the staff as they awaited the survey data: the danger of hydrological contamination of downstream areas by reactor effluent and seepage from waste products stored at the site. By December 16, when the Production Division and the Engineering Division presented their recommendation to the AEC Commissioners to acquire Fort Peck, they had to admit that they knew very little about the ground conditions of any of the candidate sites that would allow an informed judgment about their comparative ability to minimize hydrological contamination. They recommended Fort Peck because it was the only site that was known in any detail (although even it had not yet been physically inspected) and because the cost of delaying the decision--setting the schedule for constructing the reactors back for several more months-was considered to be heavier than the risks involved with the Fort Peck site. The commissioners did not accept this reasoning. They deferred their 
decision and sent the staff back to get enough information about Fort Peck and one other site to make a credible comparison.

The Production Division meanwhile had been orchestrating a general review of the old Hanford criteria to make the decision about siting experimental reactors stand on a firmer, methodically sound basis. Walter J. Williams, the division director, initiated the review. He insisted that a master plan for reactor development had to precede any firm decisions about site criteria, and the Research Division was mobilized to produce such a plan. The criteria that emerged from this plan later in the autumn did not greatly differ from the traditional ones for production reactors, but they did somewhat reduce the requirement for the volume of water needed for cooling, and, as a "secondary consideration," made it "desirable" that the soils at the site be "well-drained but not subject to rapid 'run-offs'" that would result in rapid downstream contamination. These criteria entered the survey process somewhat late, in mid-autumn, but henceforth the staff would find a new and better site than Fort peck by using them.

\section{A Premature Disclosure}

While these changes were taking place in the staff's thinking, however, the status of Fort Peck was not formally degraded. The new Deputy General Manager, Carleton Shugg, mentioned to senator Bourke B. Hickenlooper in late November that Fort Peck would probably be chosen. This premature disclosure 
prompted Montana's governor, for one, to come to Washington to press for his state's selection.

There would be trouble, later, when the AEC decided in favor of a site in another state.

\section{The choice of Idaho}

By mid-october the Engineering Division staff was soliciting new recommendations of potential sites from the corps of Engineers, the Army, the Air Force, and the Geologic survey. After the AEC decided to defer a decision on Fort Peck on December 16, the search for new sites intensified along with the search for detailed information about Fort Peck and the second leading site, Kingsley Dam in Nebraska. These two searches came under review at a meeting of the AEC Program Council on December 22 .

The division heads had new information about Kingsley Dam: it stood over a vast aquifer in western Nebraska which the state government would probably declare an irrigation reservoir at some point in the future. This factor might limit the AEC's freedom to operate the reactors at full capacity. Kingsley Dam was therefore eliminated. Then someone remarked that a new site on the Iist, the Pocatello area on the snake River in Idaho, "looked attractive." Not only did it appear to satisfy all the existing technical and safety criteria, but it also had a large government reservation in the vicinity--the Arco Naval proving Ground--which presumably could be acquired at little or no expense. The 
Council decided to take a closer look at "Pocatello" instead of Kingsley Dam before presenting its next recommendation to the Commissioners.

The Director of the Engineering Division, Roger $S$. Warner, Jr., took the next logical step. He engaged an engineering consulting firm, Smith, Hinchman \& Grylls, to make a detailed comparative survey of Fort Peck and Pocatello. The firm began work on January 5, 1949, and presented its "interim" report exactly one month later, concluding that Pocatello was preferable on many grounds. The geological substrata at Fort peck were found to be prone to "slippage" and settling beneath the weight of the Corps of Engineers dam there; its climate was more extreme in winter, which would make it necessary to install additional equipment to prevent the coolant water from freezing; and its drainage features were found more conducive to those "rapia runoffs" from the site to the nearby river which were of concern to the AEC. The Engineering Division recommended Pocatello on the strength of these findings: the soil there conformed to the new criterion--added since December--that "flat, poorly drained topography with highly adsorptive (sic) soil, is preferred to well-drained topography with impervious soils and rapid runoffs." Even though more people were actually living in the immediate area of Pocatello, the greater isolation of Fort Peck was not considered enough reason to choose it in view of its liabilities of hydrology, geology, and proximity to the canadian border (seventy miles). The commissioners accepted the survey 
report of Smith, Hinchman \& Grylls without questioning its reliability; Chairman Lilienthal called it "impressive."

The Congress was not so impressed with it, however, when the Joint Committee on Atomic Energy held a series of hearings on the choice of Pocatello in April and May 1949. The interrogation revealed a great number of irregularities about the manner in which the survey report had been compiled.

For example, the fact that the company took only $\$ 3,000$ for the job and a month to complete it was explained by the fact that they had subcontracted the survey of Fort Peck to a man from another engineering firm, who visited the place in the middle of January and, finding it completely inaccessible due to heavy snow, contented himself with calling up a local corps of Engineers officer to ask about the geology of the area. The rest he wrote up on the basis of his own "general knowledge" as a geologist. (See Appendix B for a summary.)

The congressional questioning of the AEC staff responsible for hiring Smith, Hinchman \& Grylls led to a number of embarrassing revelations about the entire selection process. The Director of the Engineering Division was criticized for awarding the contract on the basis of a recommendation by someone from another agency.

In a few minutes the questioning led back to the confusion of the proving grounds project with the "Hanford duplication" scheme; the confusion of criteria; the premature disclosure to senator Hickenlooper that Fort Peck would be chosen; the 
redrafting of criteria in the middle of the process; and, finally, the haphazard manner in which Pocatello abruptly replaced Kingsley Dam at the last moment.

The essence of the difficulty, as Deputy General Manager Shugg put it in his testimony, was that "ali these things were running at once." The method had been "knocked together" in the course of the project, and there had been several backtrackings to change the criteria, as a consequence.

The AEC approved the selection of Pocatello on March 1 , 1949. The acquisition proceedings lasted another nine months, until a presidential directive transferred the Arco Naval Proving Ground to AEC jurisdiction on December 1 of that year.

Among the hard-earned lessons that the AEC learned from the entire affair, one was put into practice right away. on January 10, 1950, the AEC announced the formation of an independent three-man Engineering Advisory Committee to advise the new Idaho Operations office in planning the development of the Reactor Testing station. The chairman of the committee was General I. J. Sverdrup, a distinguished Army Engineer in the Pacific Theatre in World War II. Sverdrup, head of the engineering consulting firm of Sverdrup and Parcel, subsequently served as chairman of survey review committees for the Savannah River and Paducah sites.

The Savannah River Site Selection (1950)

The AEC evidently learned a great deal from the siting of the Idaho Reactor Testing station. The evidence took the form of 
procedures the staff explicitly insisted upon following in the next project of its kind, the Savannah River complex, in 1950.

The idea of siting reactors away from Hanford was not new, of course. What was new was the thermonuclear weapon, which required a fuel of a different type--tritium. This project created a new level of tension throughout the AEC, the congress, and the country following the detonation of the first soviet fission device in August 1949. Earlier consideration of the idea of moving from Hanford, in 1947-1948, had been prompted by reports of the growing vulnerability of the Pacific Northwest to Soviet bombers. This concern still existed in 1950, but it was not the main reason why the AEC ultimately decided to take the long-contemplated step of finding an alternate location.

That decision was made informally, in February 1950, as conversations began in the Military Liaison committee and in the office of the AEC General Manager, Carroll. L. Wilson, about expanding the production system to provide the tritium needed for thermonuclear weapons without disrupting the production of plutonium at Hanford. Earlier the decision not to move away from Hanford had been made on the basis of cost, following the pessimistic recommendations of the Production Division. Now the decision was being assumed, by planners at a higher level, that Hanford's plutonium production was too important to disrupt by constructing additional reactors and separation plants there. The new reactors producing tritium--two of them--would be of the heavy-water moderated type, capable of being readjusted to 
produce plutonium as well. That requirement meant separation plants would also be needed at the new complex. These "strategic" considerations would determine the size of the new reservation. Iike Hanford, it would have to be large enough to accommodate several reactor areas and other plant areas spaced miles apart for safety.

There was one other serious consideration in the minds of the high-echelon AEC officers, which, though not strategic in nature, was to enter their planning for the expansion: housing. This mundane matter arose from their predecessors' failure to consider existing communities in the neighborhood of oak Ridge and Hanford a positive necessity; on the contrary, for public safety's sake as well as secrecy, it had been thought necessary to locate those complexes in areas of low population density, and the isolation criterion for siting Hanford had even specified "no town of 1,000 or more population within 20 miles." That meant the government had to build and administer whole new towns for the personnel and the temporary construction armies which poured into the area. While the exigencies of wartime might have required such a policy, the $A E C$ had no wish to repeat the "government town" experience.

Thus, when Acting Chairman sumner T. Pike invited the DuPont Company to undertake the new reactor project, he proposed the company assume responsibility for all phases of it, including designing the reactors, constructing and operating them, and finding a site. If the company found it necessary to locate the 
complex in an area that did not have enough existing communities to support it, then, Pike wrote, Dupont would also assume the obligation to build and administer such a community.

The AEC took responsibility, however, for locating the new complex out of reach of soviet bombers. The Production Division asked the Military Liaison Committee for guidance and received a Defense Department map of the United states with contoured "defense" zones outlined on it. (See Appendix C.) The "First Defense zone"-the preferred one--comprised the states of the former Southern Confederacy, exclusive of western Texas and northern Virginia and a 100-mile strip along the Atlantic and Gulf coasts (which also excluded Florida). It also included some territory to the north: Kentucky and the southernmost portions of West Virginia, Indiana, Illinois, and Missouri. Beyond this preferred zone were two others: the "Second" and "Third" defense zones, which were now within range of bombers from siberia. For the AEC's purposes, the outer defense zones included all of the "wide open spaces" with rivers and hydroelectric power in the west and the Pacific Northwest which might have made the siting of another big reactor complex a relatively simple matter of pulling out the 1948 "Hanford duplication" ilst. The Defense Department also verbally expressed a wish that the proposed facility not be located in the "Northeast Industrial Triangle," which would have made it an even more attractive target for soviet strategic bombing. 
These two conditions--the existing community infrastructure requirement and the defense zone requirement--greatly complicated matters. The same two factors also drew attention to the South, for that region was not only geographically remote from the Soviet Union but also had numerous small county towns dotting an otherwise undeveloped rural landscape. Furthermore, the southern states were eager to get large government facilities, and they would fight for this reactor complex. They sent lobbyists to President Truman's office until Truman wrote to AEC Chairman Gordon Dean in August instructing him to choose the location on its own merits, without any influence from "pressure groups of any sort."

\section{The Survey Begins}

The experience gained in siting the Idaho Reactor Proving Ground was evident in the way the AEC staff guided DuPont at the beginning of the survey.

The Production Division sent preliminary criteria to the Office of the Chief of the corps of Engineers on June 19, 1950. The corps was asked to recommend any government-owned facilities of between 100-150 thousand acres (roughly 350 square miles), within the Defense Department's "preferential area," in a "fairly isolated location," but within 15 miles or so of a town of 25,000-50,000 population. The water volume requirement $(80,000-$ 100,000 gallons per minute) was a third prime criterion, and 
least, as usual, was the requirement for a railroad and highways in the vicinity.

In the next two weeks Dupont representatives accompanied by AEC officials descended on the regional offices of the corps in the "First Defense Zone," roughly coextensive with the Corps' Ohio River, South Atlantic, and Southwestern Divisions. The visitors stressed the importance of considering all potential sites. Clearly this time they had no intention of overlooking another Pocatello. All agreed that the site should have an adequate water flow, but then the Dupont engineers produced the formula they had devised to satisfy simultaneously the requirements for isolation and for a supporting population and civic infrastructure. Their scheme was drawn in a diagram (Appendix D). The facilities and the "exclusion zone" around them would have a radius of six miles. Five and a half miles of this were the "exclusion zone," calculated according to the nowtraditional formula that required the width of the zone to be in proportion to the maximum expected operating wattage of the reactors. Beyond the evacuated exclusion zone there would be a series of "annular" distance rings (resembling the growth marks of a tree trunk in cross-section) expanding out to a distance of thirty-five miles. This outer zone had a double purpose. To satisfy the isolation requirement, on one hand, the Dupont formula decreed there would be no settlements of more than 500 population in the first, nearest "annular ring"; in the next five-mile ring (five to ten miles out), no more than 5,000; in 
the next (ten to fifteen miles) no more than 10,000. To satisfy the requirement for supporting communities, on the other hand, the formula stated that within all the "annular rings" together, five to thirty-five miles from the perimeter, there should already be several communities of over 5,000 each, totalling 25,000 population or more: in other words, the small towns having the social infrastructure of a typical rural county.

There were a surprisingly large number of places in the region that could satisfy these criteria--at least on paper. The Corps of Engineers recommended nearly 100 potential sites in the first month. The AEC Production Division thereupon requested the Corps to send detailed data about all of them. This time, unlike 1948, the staff intended to be fully aware of its options right from the start. To be further insured, moreover, the staff also requested the North Atlantic and Missouri River divisions of the Corps of Engineers to recommend sites even though these would be outside the preferred defense zone. By mid-August, detailed papers on 105 sites had arrived. The Production Division forwarded these to DuPont's Engineering Division. DuPont found that 84 of the sites satisfied the prime criteria of water, isolation, and supporting communities. This number was reduced to 17, however, when the company applied successive secondary criteria: "terrain, freedom from floods, navigable streams through the site, accessibility, climate, pumping lift, and pumping distance." 
The Process withstands Incremental Adjustments of the Criteria

The soundness of the AEC's new, systematic method of site selection was proven when the Production Division planners changed the projected number of reactors for the facility twice in the course of the next three months. Dupont's engineers received instructions to prepare for four reactors instead of two. This doubled the water requirement of the facility from 200 to 400 cubic feet per second, and brought the number of acceptable sites down from seventeen to seven. Other latearriving information about seasonal flooding and rough terrain at two of the seven eliminated them as well. This left five sites, among which the leading candidate was "South Carolina No. 5, 22 miles southeast of Augusta, Georgia," on the Savannah River.

The AEC would not repeat the mistake of choosing a site without adequately checking the procedure that had been used to recommend it. In August 1950 the AEC appointed a five-man site Review Committee, recruited from the country's most distinguished engineering and consulting firms, to review DuPont's forthcoming recommendation. They would be asked to inspect the sites on DuPont's "short list" before the AEC approved one.

In october Dupont engineers decided that considerable savings would result from using colder water to cool the reactors. They received the AEC's permission to reopen the search in the "Second Defense zone" (the Great Lakes, the Mississippi River north of St. Louis, and the st. Croix and wabash Rivers). of the ten promising sites located, they 
discarded all but two because of bad topography, inaccessibility, and lack of supporting communities. Of the two that survived, "Illinois No. 59" on the wabash took third place behind savannah River and a site on the Red River, "Texas No. 125."

The ultimate test of DuPont's siting formula for isolation versus supporting communities came in september, when the AEC increased the projected number of reactors to six. As a consequence, water requirements increased from 400 to $600 \mathrm{c} . f . s$. and the required area grew to 160,000 acres as the "exclusion zone" swelled outward around a central manufacturing area that expanded from one to twenty square miles.

\section{The Selection of Savannah River}

The changed criteria did not affect DuPont's final recommendation of the "South Carolina No. 5" site. The Savannah had purer water than the Red River in Texas, which would eliminate the need for expensive purification facilities. The Savannah was warmer than the Wabash, but the land along the river in Illinois was prime farming land, which would certainly be more expensive than the South Carolina woodlands. Besides, DuPont must have understood that the AEC could not approve exposing the richer farmland of Illinois to the hazards of a reactor complex when the land along the Savannah River was rated as "marginal" for agriculture. The Illinois site's topography was rougher than South Carolina near Aiken, and its climate harsher in winter. DuPont considered that the cheaper petroleum and gas prices in 
Texas did not compensate for the impurity of the Red River. The Savannah River site was actually outside of the "First Defense Zone" because it was less than 100 miles from the ocean, but the Defense Department did not object to that. Dupont nominated Savannah River to the AEC on November 10. The site Review committee inspected it and three other leading alternate sites and reviewed all the related data. The committee blessed the choice of Savannah River and confirmed that the procedure of selecting it had taken all criteria into proper account.

The Process Hits a Snag--The Evacuation of a Town

Before the AEC met to confirm DuPont's choice on November 22 , the company changed its requirement for the area of land that would have to be taken. The company had learned that the reactors' operating power could be increased 25 percent for several months of the year. Since the size of the "exclusion area" around the reactor complex was calculated on the basis of wattage, this implied increasing the 5-1/2 mile-wide zone to 6 miles. Dupont also wanted to increase the traditional distance between reactors from 1 to 2 miles for the same reason, and suggested that $2-1 / 2$ miles' distance would provide more security against collateral damage from "strategically placed missiles."

Besides wishing to expand the perimeter all around, DuPont wanted to move the site boundary closer to the Savannah River to shorten the distance and hence the cost of pumping water to the reactor area. The company also wanted to acquire the land 
adjoining the highway and railroad on the northwest side of the perimeter to regulate anticipated private development there. These "tactical". considerations made a total increase of 80,000 acres necessary, expanding the size of the reservation from 160,000 to 240,000 acres. One consequence of this specification was that the town of Ellenton would have to be evacuated.

The Public Interests Reconciled

Well before they heard this news the AEC Commissioners realized that they would be responsible for reconciling Dupont's choice with all of the nonengineering considerations dictated by the public interest. The Production Division had obtained the approval of the Defense Department, the Commerce Department (including the weather Bureau), the Department of the Interior, and even the Federal Housing Authority, when DuPont had wanted to reopen the search to find colder water at a more northerly site. Chairman Gordon E. Dean was inclined to allow it. He did not want the Defense Department's defense zone restrictions to cause Dupont to neglect sites that would potentially be better than the ones already in hand. Dean was opposed by commissioner Pike, who felt that reopening the search would delay the construction beyond tolerable limits. This discussion indicated that the Commissioners seriously intended to challenge DuPont's recommendations if these conflicted too badly with other considerations that had not been emphasized in the form of criteria. 
This resolve was tested when the commissioners met on November 27 to approve Savannah River. The commissioners were willing to accept the company's choice of that location, but several of them objected to increasing the area in a way that would engulf more communities. The commission asked Dupont to review this proposal thoroughly, to learn whether it was really necessary to increase the spacing of the reactors and hence the exclusion area. In effect, the dissenting commissioners were saying that DuPont's judgment had failed to respect the secondary criterion--which had never, in fact, been emphasized at any stage of the process-to spare the public unnecessary evacuations. Dupont took umbrage at this and tartly answered the AEC that the Commission, not the company, was contemplating a decision that would violate the public interest by allowing communities to remain on land that was needed for the most secure and economical operation of a capital national asset. If the commissioners allowed Ellerton to stay on the reservation, as some of them proposed, they would be guilty of exposing the public to a radiation hazard which had long been considered unacceptable.

The AEC accepted these arguments and approved the extension of the site boundary. Construction crews poured into the Aiken vicinity in January 1951, swiftly overwhelming the capacity of the area to accommodate them. A congressional hearing was called in February, and the commission was invited to explain what provision it had made for housing at Savannah River and at the Paducah gaseous diffusion plant which was also under 
construction. Commissioner Henry D. Smyth replied that the accessibility of existing housing had indeed been considered in the selection, but the commission had concluded that no site could have satisfied this as well as all of the technical criteria. The existing communities nearby had been considered no more than nuclei of the housing communities that would be developed later. Congress did not question these assertions. No blame was placed on the AEC's conduct this time.

Postscript: Close Down (1953-1963)

By the time the first of the Savannah River reactors went into operation in 1953, the commission already realized that the two waves of expansion in 1950 through 1952 had overbuilt the production system. The new Republican Administration had committed itself to a fiscal austerity program, and president Eisenhower instructed AEC Chairman Lewis L. Strauss to reduce expenditures as well. Strauss ordered a staff review of the system, and one of the recommendations was to put one of the three fabrication facilities on a standby status. The choice was between the oldest facility, at Hanford; the newly opened one at Rocky Flats; or a third, soon to be completed, at the savannah River complex. The Hanford and Savannah River facilities had been sited according to the policy of making each of the two reactor complexes able to fabricate its own plutonium. All three facilities combined gave the $A E C$ enough reserve capacity to convert the stockpile of plutonium devices into new 
configurations dictated by military needs in wartime. Meanwhile, the nonemergency load would be distributed more or less equally among the sites.

Strauss's review caused the first revision of this policy of redundancy. The AEC decided to place the newest of the facilities on standby status--the one at Savannah River. The savings, strauss reported to Eisenhower, would be a million dollars a year in operating costs after 1955. The sixth reactor at Savannah River was never built. By 1963 there were fourteen others, five at Savannah River and nine at Hanford. In 1962 President Kennedy directed that production capacity should be reduced to match the Defense Department's ten-year stockpile projections. At first the AEC staff believed that it would be possible to make the necessary reductions by lowering production output simultaneously at all of the gaseous diffusion plants. However, in mid-February 1963 Defense secretary Robert $S$. MCNamara informed AEC Chairman Glenn T. Seaborg that plutonium weapons requirements, specifically, would be lower by 20-50 percent by the end of ten years. Thereupon seaborg ordered the Division of Military Application to prepare a schedule of "plutonium-equivalent retirements" to be spread across the reactor complex.

It would have been logical on economic grounds to shut down all of the operations at one of the two complexes, preferably Hanford, since most of its reactors were older than those at Savannah River. Nevertheless, following the recommendations of 
DMA, Acting Chairman Robert $E$. Wilson informed President Kennedy in August 1963 that the Commissioners preferred to keep both of the reactor complexes open in order to dilute the economic impact and to maintain the capability of both to return to full production within a reasonable time in a national emergency. Consequently, the commission decided to alternate reactor closings between the two sites, beginning with the oldest and least economical.

This philosophy guided the first year's closings of one reactor at each of the two complexes in 1964. Thereafter, the closings at Hanford came more often. By early 1971, all of the Hanford reactors, except for $\mathrm{N}$ reactor, were closed. 


\section{Hanford Site -1942}

AEC 1140. Atomic Energy Commission History of Expansion of AEC production Facilities, August 16, 1963. DOE Secretariat Files, Box 1435, Folder I\&P 14 History.

Details of postwar expansion of nuclear production.

AEC 1149. Press Release: Statement by Glenn T. Seaborg, Chairman of the AEC, January 8, 1964. DOE Secretariat Files, Box 1403, Folder 3.

Explanation and justification of plutonium and enriched uranium production facilities.

AEC 40. Various reports discussing growing obsolescence of early nuclear production facilities and recommendations for action. DOE Secretariat Files, Box 1402, Folder 7.

Groves, Leslie R. Now It can Be Told: The story of the Manhattan Project. New York: Harper \& Brothers, 1962 .

Hewlett, Richard G., and Anderson, Oscar E., Jr. A History of the Atomic Energy Commission. Vol. I: The New World, 19391946. Washington, D.C.: U.S. Atomic Energy Commission, 1972 .

Jones, Vincent $c$. Manhattan: The Army and the Atomic Bomb. Special studies, U.S. Army in World War II. Washington, D.C.: U.S. Army center of Military History, 1985.

Manhattan District History. Book IV - Pile Project, X-10: Vol. 3 - Design, and Vol. 4 - Land Acquisition, HEW. Manuscript, 1948, DOE Archives.

Detailed descriptions of the site selection criteria and proposed plans for the production plants.

The Proposed Duplication of Hanford Facilities $(1947-1948)$

AEC 81. Dispersal of Plutonium Facilities - Additional Pile Production Facilities at Hanford, April 19, 1948.

AEC 81/1. Duplication of Hanford Production Facilities, July 6, 1948 . 
AEC

$81 / 2$. Duplication of (Revision), July 26, 1948.

AEC 81/3. Decision on AEC 81/2. Duplication of Hanford Production Facilities (Revision).

Minutes of 184th AEC Meeting, July 8, 1948.

Minutes of 372nd AEC Meeting, February 15, 1950.

Idaho Reactor Testing Station (1948-1949)

AEC 142. Reactor Safeguard Committee to Dr. George Weil, Reactor Branch, AEC, September 10, 1948 .

AEC 142/1. Site Selection for Reactor Testing station, December 14, 1948 .

AEC 142/2. Reactor Safeguard Committee statement on Proving Ground site - Preliminary Draft, December 15, 1948.

AEC 142/3. Site selection for Reactor Testing station, February 15,1949 .

AEC 142/4: Reactor Safeguard committee statement on the Pocatello, Idaho, Site for Reactor Testing station, February $25,1949$.

AEC 142/5. Site Selection for Reactor Testing station, March 1, 1949 .

AEC 152/2. A Reactor Development Program, December 8, 1948 .

Minutes of the 191st AEC Meeting, September 10, 1948 .

Minutes of the 226th AEC Meeting, December 16, 1948.

Minutes of Program Council, December 16, 1948.

Minutes of Program Council, February 14, 1949.

Minutes of the 246 th AEC Meeting, February 18, 1949.

Hearings Before the Joint Committee on Atomic Energy, Congress of the United States, 81 st Cong., lst sess., on selection of Site for Reactor Test Station (April 14, and May 10, 1949). Washington, D.C.: U.S. Government Printing office, 1949. 
Savannah River - 1950

AEC 361/4-5. Site selection for DuPont Production Facility, November 17,1950 .

AEC 361/6. Site selection for DuPont production Facility, November $20,1950$.

AEC 361/7. Site selection for Dupont Production Facility, November $22,1950$.

AEC 361/8. Site selection for DuPont Production Facility, November $27,1950$.

AEC 361/9. Boundaries for Savannah River Plant site, December 14, 1950 .

AEC 361/10. Boundaries for Savannah River Plant site, December 26,1950 .

Minutes of the 490 th AEC Meeting, November 3, 1950.

Minutes of the 495th AEC Meeting, November 20, 1950.

Minutes of the 497th AEC Meeting, November 22, 1950.

Minutes of the 512th AEC Meeting, December 28, 1950.

Hearing Before the Joint Committee on Atomic Energy, Congress of the United States (February 16, 1951), 82nd Cong., Ist sess., Housing for Savannah River and Paducah Sites.

Postscript: Close Down (1953-1963)

AEC 484/2. Plutonium Fabrication Facilities, November 18, 1953.

AEC 580/172. Stockpile Requirement, December 14, 1962.

AEC 580/178. Budgetary Implications of Stockpile Requirements, February $4,1963$.

AEC 580/180. Production through 1972, February 11, 1963.

AEC 580/184. Plutonium and Tritium Production Planning, May 6, 1963 .

Wilson to President Kennedy, letter of August 21, 1963. 


\section{GASEOUS DIFFUSION PLANTS: PADUCAH AND PORTSMOUTH}

\section{Summary}

The rationale for the decision to locate additional gaseous diffusion complexes at sites other than Oak Ridge was the need for increased production and "security through dispersion." Two major considerations shaped the primary criteria: (1) secure production capacity demanded locations within the "strategically safe" zone; and (2) the massive amounts of electricity consumed in the gaseous diffusion process (85-90 percent of plant operating costs) dictated the choice of sites with readily available, low-cost power. The korean war imposed rigid time constraints on the selection effort, especially in the 1950 selection, which was confined to sites already owned by the government. After the acquisition of the Kentucky ordnance Works at Paducah, in November 1950, the Commission experienced some minor difficulties in settling on a power supply contractor. Chronic labor strikes and a severe housing shortage were more serious problems which contributed to construction delays at Paducah.

With the construction of additional capacity under way, the 1952 site selection was a more methodical, cautious exercise which reflected the lessons learned at Paducah. However, factors beyond the commission's control dictated the ultimate choice. Politics were a major consideration in 1952. Vehement opposition to an AEC facility at Louisville and the refusal of cincinnati 
craft unions to accept the AEC's contract proposals were critical factors in selecting portsmouth, the Commission's third choice.

\section{Background}

Prior to the outbreak of the Korean War, the AEC's entire gaseous diffusion capacity was concentrated at oak Ridge. studies on isotope separation by gaseous diffusion began in 1940 , and by the end of World War II, the oak Ridge complex featured two plants, $\mathrm{K}-25$ and $\mathrm{K}-27$. Increasing production demands and concerns over the possibility of sabotage or enemy attack prompted a 1949 study of the AEC's production capacity by the Director of production, walter J. Williams. Williams concluded that $k-25$ and $k-27$ would not satisfy the military's requirements. But, williams added, oak Ridge was not unduly vulnerable to attack. Subsequently, the commission approved an additional plant for Oak Ridge, $\mathrm{K}-29$, in March 1949. The military continued its pleas for still more production capacity, however, and the outbreak of the Korean war in June 1950 found the Oak Ridge contractor, union carbide, immersed in work on a second additional plant, $\mathrm{K}-3 \mathrm{l}$.

\section{Beyond Oak Ridge: Paducah}

The hostilities in Korea, erupting less than a year after the first Russian nuclear detonation, heightened the pervasive and nagging fear that the United states was in danger of losing its nuclear edge. On August 8 , 1950, the National security 
Council asked the Atomic Energy Commission and Department of Defense to determine the scale and effort which would be required to increase fissionable materials production. The commission's participants in the AEC-DOD joint working group were williams; the Director of Military Application, Brig. Gen. James McCormack, Jr.; and the Director of Reactor Development, Laurence $R$. Hafstad.

The joint working group assumed as a baseline goal the doubling of production capacity. Toward that end the group recommended as an interim measure, pending a definitive assessment of materials requirements, the construction of an additional 1,000 gaseous diffusion stages at two new plants, c-31 and C-33, to be completed by November 1953. The group assessed the strategic and massive power supply requirements of a gaseous diffusion complex and argued in their september 6 report that the "initial and major" portions of the new capacity should be located at a site removed from oak Ridge. A new location would disperse, and thereby enhance the security of, uranium-235 production capacity. At a new location the AEC sought the flexibility to duplicate the existing oak Ridge capacity, if necessary.

The joint working group stressed the urgency of its recommendations and set December 1,1950 , as the deadine for acquisition of a new site. Financing for the facility's power plant should be in place and design and procurement initiated by January 1, 1951. In the interim, power would come from existing 
or already planned facilities. President Truman approved the expansion plan on october 9 .

Even before the joint working group assumed its mandate, however, the commission began the site selection process in hopes of moving forward immediately upon presidential approval. Williams, assisted by the oak Ridge manager, samuel R. Sapirie, took the lead; on July 31, 1950, he wrote to Edward Falck, Director of the office of Energy and Utilities, National security Resources Board (NSRB), to request a list of sites within the "strategically safe" zone but at least 150 miles from Oak Ridge which met the power supply requirements for the gaseous process. 1 Robert BIUm coordinated the NSRB survey, assisted by a team of government and industry power supply experts.

Although the NSRB survey took into account other factors which would ultimately figure in the final site selection, such as labor supply, availability of transportation, and proximity to established communities, the primary criteria in this first level survey were strategic safety and power supply. On the advice of Paul J. Larson, Director of the office of Civil Defense, NSRB restricted its search to an area in the southeastern United states roughly bounded by the inland portions of virginia, the Carolinas, Georgia, Alabama, Mississippi, and Louisiana; eastern Texas and oklahoma; the extreme southern portions of Missouri,

1. Williams' letter is not included in the AEC Secretariat files researched for this report, but was referred to in Falck's August 31 reply, attached as Appendix "D" to AEC 372/2, October 16, 1950 . 
Illinois, and Ohio; the northernmost tip of Kentucky; and the southwestern half of West Virginia--the same "strategically safe" zone employed in the selection of the Savannah River site. By August 31, Falck reported that the team had identified eight geographic areas which satisfied the power supply requirements. Each had the necessary interim power supply--330,000 kilowatts-as well as a potential permanent new generating capacity of 750,000-1,000,000 kilowatts. The areas targeted for further investigation were the lower White-Mississippi River; Ft. Smith, Arkansas, vicinity; the Ouachita-Mississippi River; the lower Tennessee-Cumberland River; the upper Cumberland River; the Green River, near Bowling Green; the lower Ohio River; and shreveport, Louisiana.

on september 7, Williams and sapirie reported to the Commissioners that twice the full capacity of oak Ridge would be required by 1953 to meet 1956 stockpile goals. 2 They recommended that the commission proceed with plant design, equipment procurement, and site selection for a new facility. The Commissioners approved the report and recommendations on September 13, and formally delegated the task of site selection to a team of Oak Ridge staff headed by Williams and sapirie. The Oak Ridge staff proceeded with a "second level" survey, using specific selection criteria developed by Union carbide on the basis of its experiences with gasous diffusion at oak Ridge. December.

2. K-29 was completed in January 1951; K-31, the following 
They examined only government-owned properties within the eight target regions. Williams explained the rationale for limiting the search to government-owned properties in his september 21 letter to Military Liaison Committee Chair Robert LeBaron: "as much as six months' time could be saved if a site meeting the necessary criteria and already owned by the government could be located"; moreover, the selection of a government site would "obviate the need for time-consuming condemnation and acquisition proceedings." 3 The evaluation criteria for this second-phase selection were more specific and detailed than the first-phase criteria. Major considerations included a continuous supply of water, preferably with low mineral content, at a minimum rate of seventy-five cubic feet per second; housing for approximately 1,500 operations employees and their families; moderate average temperature without seasonal extremes; no history of major floods, tornadoes, or earthquakes; proximity to rail, highway, and air transportation; an adequate labor market, preferably with a sufficient number of skilled tradesmen, low labor costs, and a history of good labor-management relations; and an available land area of three by four miles which included at least one square mile of "reasonably level" land. The ideal site would also have subsoil which could sustain a relatively high bearing load, good natural drainage, and nearby sources of essential building materials. The oak Ridge staff examined nineteen sites and narrowed the selection to three which best met the most

3. AEC 372, September 29, 1950. 
requirements: the Kentucky Ordnance works at Paducah; the Louisiana ordnance Plant at Shreveport; and the Longhorn ordnance Works at Marshall, Texas.

None of the three sites precisely fit all of the second level selection criteria. The Army had disposed of all but 1,400 acres at Paducah, although the oak Ridge staff believed that surrounding tracts could be readily reacquired. Although the existing facility offered a minimum area sufficient to satisfy the immediate acreage requirements, a protection belt could be added later. Paducah was not a well-developed industrial area, and the survey team projected a temporary shortage of skilled craftsmen. The Louisiana and Texas sites were subject to immediate reactivation in case of emergency, and even if the commission could acquire enough land at either site to begin construction on schedule, it would face the administrative nightmare of joint tenancy and dual administration with the Army that had proved so troublesome at the Burlington, lowa, plant. In addition, the Louisiana clay and the Texas salt lacked the necessary load-bearing capability. Other disadvantages included the fact that the water supply at shreveport was off-site and vulnerable to attack, and Longhorn was too far removed from a city large enough to provide adequate labor or housing.

of the three locations, the Kentucky ordnance Works was clearly superior. The Oak Ridge staff anticipated that the AEC would be able to take over the facility quickly since the Army had already designated the Works as excess and had transferred 
custody to the General services Administration. Moreover, Paducah satisfied more criteria (power, water, terrain, climate, transportation, labor) than either of the other sites. Williams concluded that none of the other areas investigated "offer as high a degree with assurance of meeting the overall objectives" as Paducah. He also warned that "the investigation of possibilities other than government-owned properties would result in a delay of approximately six months in the construction program." 4

The commission acted quickly and decisively on williams's recommendation. The site Review committee that had reviewed the site selection process for the Savannah River reactor complex considered Williams's report in mid-october. After a brief visit to the ordnance works, the committee approved the Paducah site. on october 18, just nine days after the President had authorized the expansion of uranium-235 production capacity, the Commissioners concurred. The following day, AEC Chairman Gordon Dean wrote to secretary of the Army Frank Pace requesting transfer of the Kentucky ordnance works to the AEC. In a cordial but hurried exchange of correspondence between the office of the Chairman and the office of the secretary, the AEC and the Army agreed that the AEC would assume responsibility for relocating the Army's TNT production capacity from Paducah to another site. The relocation would involve dismantling, transporting, and reinstalling production equipment, as well as the construction of

4. $\operatorname{AEC} 372 / 2$, october 16, 1950. 
suitable buildings and utilities. The Army estimated the total cost of the effort at $\$ 26.5$ million. Complete duplication of the Ordnance Works would be a more expensive alternative, however, at a cost to the AEC of $\$ 37.5$ milizion. The AEC accepted these terms on November 7; by November 10, the Munitions Board had approved the transfer of the Kentucky ordnance Works to the AEC; and a week later the GSA gave the AEC permission to occupy the site. Williams agreed to meet with ordnance Department representatives on November 21 to work out the details and logistics of relocating the Army's TNT production facility at another site.

Given the extreme time constraints, the commissioners could ill afford to relax their efforts on other fronts while awaiting the green light from the Army. In late October, they chose Union Carbide as managing contractor on the basis of the company's experience with gaseous diffusion at oak Ridge. Construction of C-31 began early in 1951, and by summer, C-33 was under way. At Paducah, the selection process had apparently worked well, especially in light of the severe time pressures imposed by the international situation.

Despite such an auspicious start, however, problems began to emerge which might have been avoided had the site selection proceeded at a less hectic pace. The first indication of trouble appeared in the selection of the power supply contractor. In the final stages of the site selection, NSRB had suggested that either American Gas \& Electric or TVA would be a likely source of power for Paducah. On the day that the commission made its final 
selection, the AEC sent requests for proposals to both companies. When the commissioners met on November 8 to consider the two proposals, however, they immediately rejected the American Gas \& Electric bid since it involved transmission over too great a distance.

Commissioner Thomas E. Murray had serious reservations about the TVA proposal as well; TVA planned to build a new six-unit generating facility, supplemented by two additional units at the New Johnsonville steam Plant. Murray argued that the primary rationale for a new facility removed from oak Ridge was to guarantee additional, independent capacity: additional capacity without an independent source of power would be self-defeating. The Commissioners, with Murray dissenting, accepted the TVA proposal on merit and agreed to resolve the problem of siting the generators later. Commissioner T. Keith Glennan later complained that the commission should have raised the power supply issue earlier. Since the selection of a power contractor was so closely linked to the selection of a site, the commission should have considered the issues together. The power supply question was resolved by May 4, 1951, when the commission entered into a contract with Electric Energy, Inc., a consortium of utility companies which agreed to build a private plant seven miles from the ordnance works. The commission continued negotiations with TVA for a second plant, to be built with TVA funds.

As early as February i951, the shortage of housing for construction workers in the Paducah area was so acute that the 
Joint Committee on Atomic Energy (JCAE) held special hearings on the problem. Representative Carl J. Durham warned that, unless resolved, the housing shortage could cause up to a year's delay in the production schedule. The AEC projected a peak construction employment of 12,000 by October 1951; a Housing and Home Finance Agency survey located only 600 available rooms in the vicinity. To remedy the problem, the commission supplied prefabricated housing and dormitory facilities and sought additional rental housing under the National Housing Act.

Labor problems and work stoppages posed a graver threat to the Paducah construction schedule. Williams had admitted in his October report that skilled tradesmen were scarce at Paducah, but had projected that the shortage would be only temporary. The commission experienced considerable difficulty, however, in finding skilled workers who would accept the salaries offered. Many of those who did accept employment went on strike for higher wages, and work stoppages were a chronic problem by the summer of 1951. By September the situation was so serious that Dean personally appealed to the unions in an attempt to get construction back on schedule.

As work on $\mathrm{C}-3 \mathrm{I}$ and $\mathrm{C}-33$ progressed at Paducah, hampered by labor problems but still "more or less" on schedule, the Joint committee and the military establishment clamored for further increases in America's nuclear capability. In 1951 the Commissioners were no less sensitive to the exigencies of war and the apparent expansion of the Soviet Union's nuclear arsenal, and 
the AEC had continued its own studies of production expansion. However, the commissioners favored a less precipitous approach to expansion than either the JCAE or the military. They argued for a realistic assessment of existing and authorized production capacity as well as a precise definition of military requirements, and would have preferred to concentrate on making the most of existing facilities to embarking on additional expansion programs. Nevertheless, the President authorized the further expansion of plutonium and uranium-235 production capacity on January 16, 1952, and the Commissioners subsequently found themselves considering another site for yet another gaseous diffusion complex.

With work on $c-31$ and $c-33$ under way, the AEC was not under the severe time constraints that had influenced the 1950 site selection process. Lessons learned at Paducah and in the selection of other sites acquired during the 1950 expansion program were put to good use in the search which eventually led to Portsmouth. Again Williams directed the site selection effort with support from Sapirie and the Oak Ridge staff. This time the selection team could afford to conduct a less hurried, more methodical search for a second site away from oak Ridge. However, political considerations, which had barely affected the 1950 decision, if at all, proved to be a major factor in 1952, a presidential election year. This and factors beyond the commission's control ultimately determined the selection of the Portsmouth, Ohio, site. 


\section{Site III: Portsmouth}

As early as June 1951, the Oak Ridge staff began active planning for additional uranium-235 and plutonium capacity. Additions to the Oak Ridge and Paducah complexes and the construction of a third facility would increase U-235 production capacity by 150 percent and plutonium capacity by 50 percent. With the completion of a fourth and final plant, the respective production increases would be 200 percent and 100-200 percent. oak Ridge recommended the siting of two additional facilities at locations which would permit combined operation, and on october 19, 1951, the Acting Director of Production authorized Oak Ridge to begin the search for site III. Stone \& Webster Engineering corporation, the survey contractor, recommended cincinnati, ohio, as the best location for Site III on March 4, 1952.

Stone \& Webster had the benefit of the Commission's earlier experiences; Oak Ridge provided them with the reports and information used in the selection of the Paducah, Savannah River, and Weldon Spring, Missouri, sites. The company followed the same "two-level" evaluation process used to select the Paducah and Savannah River sites. In the first phase, stone webster surveyed the "safe" zone for geographical areas with enough lowcost power and water for a diffusion complex. Another major consideration during the initial survey was the population base: the commission was not anxious to repeat the oak Ridge experience and preferred not to construct another "government town." The availability of government land was considered advantageous, but 
was not a major requirement for site III. Stone \& Webster obtained power cost estimates but no other specific data during the first level survey, and did not send investigators into the field.

By December 7, 1951, the survey had focused on seven areas: three locations along the ohio River Valley; in oklahoma, the Neosho River Valley; the Coosa River, from Birmingham to Gadsden; the Red River, from Shreveport to Texarkana; and the Kansas Cityst. Joseph, Missouri, area. The ohio River Valley was the most attractive region. Fuel costs were relatively low and the ohio River provided a dependable water supply. In contrast to the other areas, only the ohio River area had adequate power for the crucial "interim" period before the new facility's power plant was operational. In the event of a shutdown or reduction in operating levels, a gaseous diffusion complex situated in this region would be subject to cancellation costs substantially lower than the AEC could expect to incur in other areas, since the area's industrial base could easily absorb the excess power which would be released. The housing and labor resources of the ohio Valley could easily accommodate the planned facility. Within the preferred general area, the survey targeted three more specific locations for further evaluation in the second-phase investigation: Louisville, Portsmouth-Chillicothe, and Ashland, Kentucky-Parkersburg, west Virginia.

On January 9, 1952, the Commissioners reviewed the firstphase survey and authorized more intensive investigation of sites 
in the ohio River region. With a less pressing deadine than they had faced in selecting the Paducah site, and mindful of the consequences of their haste, the commissioners also authorized preliminary negotiations with thirteen local power companies.

With the selection narrowed down to a general region, stone \& Webster visited a number of possible sites which they evaluated according to more detailed criteria. These were essentially the criteria used to select the Paducah site, but with two significant changes which reflected the lessons learned at Paducah. At Paducah, the Commissioners had woefully underestimated housing requirements for construction and operations personnel; site III would require a location which could absorb 2,500 operating employees and a peak construction force of 30,000. Anxious to avoid the incessant work stoppages that had plagued the Paducah effort, stone \& Webster reported on the history of labor management relations for each area considered. The "security through dispersion" dictum which propelled the Korean War expansion programs found expression in the requirement that Site III be located at least 150 miles from both Oak Ridge and Paducah. Site IV, in turn, would be located at least 150 miles from each of the other three.

Three contenders emerged from stone \& Webster's second-phase survey: Louisville, Cincinnati, and Portsmouth. Portsmouth was a weak third choice because of its relative remoteness from a major population center and deficient highway system, but Louisville and cincinnati were strong possibilities. The two 
cities were equally suitable from an energy standpoint, had roughly the same climate, and were equally secure. Louisville had a less expensive, more immediately available water supply; better access to rail, air, and highway transportation; subsoil with a higher bearing capacity; and a labor surplus. Cincinnati's greater population, however, promised more housing for construction and operating personnel.

Either site seemed an ideal location for Site III, and the final verdict was mixed. Stone \& Webster preferred the cincinnati site; Sapirie argued in favor of Louisville. The matter was referred to the site Review Committee, 5 which visited Louisville, cincinnati, and Portsmouth in late February. By the time the Committee met on March 19 to settle the question, however, there was an additional factor to consider: local politics.

Even before the President authorized the 1952 expansion, the location of AEC sites had been a political issue. As early as November 1951, Republican Senator Milton R. Young of North Dakota had lobbied the commission for a diffusion facility in his state. He argued that the North Dakota Iignite reserves would provide low-cost power in large amounts; an additional attraction was the availability of huge tracts of unimproved public land in a strategically safe area. Although the commission never seriously

5. Walter S. Finley, J. G. White Engineering; James F. Towers, Ford, Bacon \& Davis, Inc.; A. T. Waidelich, the Alistin Company; and H. L. Bunce, Jr., Stone \& Webster. Bunce did not review the site III survey report. 
considered a North Dakota location, Young was relentless in his demands. At the February 27, 1952, Commission meeting, by which time the search had been narrowed to the ohio River Valley, Dean cautioned that the commission should "marshall sufficient data to justify the rejection of other areas." on March 17, the Commissioners and General Manager Marion $w$. Boyer met with Senator Young, North Dakota Governor Norman Brunsdale, and representatives of area businesses and utilities to explain why the new facility would not be located in North Dakota. Citing the disadvantages of placing the new facility in North Dakota-uncertainties of the lignite process, isolation, and lack of a "dump" market in the event of a shutdown--the commissioners tried to discourage further lobbying. The Director of Construction and supply subsequently prepared a report on the feasibility of using lignite for a steam plant at site III and informed the Commissioners on March 21 that lignite generation was still in the experimental stages. Although the study had evaluated the possibilities of both Texas and North Dakota lignite, its primary purpose was clearly to mollify young. The report evaluated the drawbacks of Texas lignite, but pointed out in conclusion that the same problems existed in North Dakota, "where additional factors are introduced by climate and weather." 6

The citizens of Louisville had equally strong sentiments about the site selection, but unlike the North Dakota lobby, they steadfastly objected to the siting of a diffusion plant in their

6. AEC 509/1, March 21, 1952. 
area. The proposed Louisville site was situated in Jefferson and ordham counties, two miles from a residential area and three miles from the standard Golf and country club. on March 19, Rayburn Watkins, Administrative secretary of the Louisville Chamber of Commerce, informed Dean that the local population was vehemently opposed to the construction of an "atomic plant" in the area. The directors of the chamber warned that Louisville was already hard-pressed to absorb its recent industrial expansion. Area schools, hospitals, and other facilities were already over-burdened, and Louisville had no surplus labor to offer. on March 19, the Site Review Committee, while acknowledging that the Louisville site was suitable in many respects, noted that the site did not offer sufficient room for subsequent expansion. More important in the final determination, however, were the widespread protests from area business and civic groups. The site Review Committee eliminated Louisville from consideration, and williams informed the commissioners that Cincinnati was the preferred site.

cincinnati was not an optimum choice, however, and the commissioners were reluctant to settle on the site without additional investigation. In his october report, williams had noted that at nearby Fernald, some of the skilled craft unions demanded double-time pay for second-shift work. If the unions remained intransigent, the additional labor costs for site III would run approximately $\$ 64$ million. Williams therefore recommended that the commission proceed on the assumption that 
the new plant would be located at Cincinnati but that they reconsider Louisville in the event that the craft unions held fast to their demands. On April 3 the Commissioners concurred and authorized further planning for a cincinnati plant, to include the solicitation of power proposals and negotiation with local craft unions. Early in July the Commissioners selected Peter Kiewit Sons, Inc., an Omaha construction company, as contractor for the new plant and directed the company to begin negotiations with craft unions in the Cincinnati area as well as at Louisville and Portsmouth. The Commissioners authorized Kiewit to disclose that the proposed contracts were for work on an AEC facility but requested that they refrain from a public announcement of negotiations.

By the time Boyer reviewed the situation in late July, serious problems had erupted in Cincinnati. The AEC had experienced work stoppages at Fernald over the issue of doublepay for shift work, and the unions could be expected to follow a similar tack at site III. Unions in the depressed Portsmouth area, however, were eager for the additional jobs that the new project would provide. They did not demand as high premiums for second-shift work as the cincinnati unions and agreed that they would resolve any future demands, except for general wage increases, without striking. Moreover, public sentiment at Portsmouth was strongly in favor of an AEC facility.

The results of Kiewit's labor survey precluded further consideration of cincinnati. The craft unions insisted that the 
new plant be a "closed shop" and remained firm in their demands for double pay for second-shift work. The commissioners reviewed Kiewit's report and other site selection data on August 7 . Five days later, they approved Portsmouth as the site for the Commission's third gaseous diffusion facility; the precise location was a 6,500-acre tract of privately owned land in Pike county, ohio, twenty-two miles upstream from portsmouth on the Scioto River. The depressed Portsmouth area lacked sufficient housing for the new plant, but the commission's previous experience at Paducah and timely passage of the 1951 Defense Housing and Community Facilities and services Act facilitated advance planning to forestall the problem. At Gordon Dean's request, the Housing and Home Finance Agency agreed to provide temporary housing for construction workers with families and to construct permanent housing for the operating personnel. The AEC would provide housing for unmarried construction workers.

In selecting site III, the commission had estimated only the approximate land requirements. They had approved the Portsmouth site in anticipation that further study and the actual layout of the facility would define more precise acreage requirements. Based on a review of more extensive topographical data, and the final layout of the complex, sapirie and the portsmouth manager recommended reducing the land requirements from 6,500 to 3,700 acres. By the end of June 1953, the commission had acquired approximately 2,701 acres by purchase and condemnation, and by December construction was well under way. 
Hewlett, Richard G., and Anderson, Oscar E., Jr. A History of the United States Atomic Energy Commission. Vol. I: The New World, 1939-1946, and II: Atomic Shield, 1947-1952. Washington, D.C.: U.S. Atomic Energy Commission, 1972.

Major Activities in the Atomic Energy Programs, January-June 1951. Washington, D.C.: U.S. Atomic Energy Commission, 1951.

Eleventh Semiannual Report of the Atomic Energy Commission. Washington, D.C.: U.S. Atomic Energy Commission, 1952.

Major Activities in the Atomic Energy Programs, January-June 1952. Washington, D.C.: U.S. Atomic Energy Commission, 1952 .

Thirteenth Semiannual Report of the Atomic Energy Commission. Washington, D.C.: U.S. Atomic Energy Commission, 1953.

Major Activities in the Atomic Energy Programs, January-June 1953. Washington, D.C.: U.S. Atomic Energy Commission, 1953.

Major Activities in the Atomic Energy programs, JuIy-December 1953. Washington, D.C.: U.S. Atomic Energy Commission, 1954.

AEC 348/3. September 8, 2950 .

\section{Paducah}

U.S., Congress, Joint Committee on Atomic Energy. Housing for the Savannah River and Paducah Sites. $82 \mathrm{~d}$ Cong., 1 st sess., February 16, 1951.

AEC Staff Papers:

AEC 372, September 29, 1950

AEC 372/1, October 13, 1950

AEC 372/2, October 16, 1950

AEC 372/3, October 18, 1950

AEC 372/4, October 26, 1950

AEC 372/7, November 15, 1950

AEC 385, November 22, 1950 
Minutes of AEC Meetings (excerpts), 487, October 25, 1950 ;

491, November 8, 1950; and 492, November 9, 1950, AEC Secretariat Files, DOE Archives.

Notes on Conference with Utilities Representatives, November 15, 1950. Folder 635.41 (9-21-50), Paducah site, Vol. 1. AEC Secretariat Files, DOE Archives.

\section{Portsmouth}

AEC Staff Papers:

AEC 537, April 2, 1952

AEC 537/1, April 2, 1952

AEC 537/4, May 20, 1952

AEC 537/5, May 22, 1952

AEC 537/6, July 22, 1952

AEC 537/11, August 11, 1952

AEC 537/12, August 20, 1952

AEC 537/15, February 19, 1953

Minutes of AEC Meetings (excerpts), 671, March 17, 1952; 724, July 16, 1952; 728, August 7, 1952 .

Roy B. Snapp to Commissioners and General Manager, Meeting with Senator Young, March 17, 1952. Folder PLB\&L 2, Portsmouth Area, Vol. 1, AEC Secretariat Files, DOE Archives.

Housing and Home Finance Agency, AEC Press Release No. 444, september 8, 1952 . 
IV. FABRICATION, ASSEMBLY, AND OTHER FACILITIES

Although the siting projects described in this chapter happened in succession (and often overlapped in time) and therefore developed in a certain relationship to each other, for the sake of convenience they are presented here by generic type: feed processing, $H E$ fabrication, plutonium fabrication, and initiator assembly facilities.

1. The Fernald Feed Materials production center (1950-1951)

Before 1953 the processing of feed materials was done by three companies in three widely separated cities. The Mallinckrodt Chemical works in st. Louis processed ore into uranium dioxide ("brown oxide"); the Harshaw Chemical works in Cleveland processed the brown oxide into uranium hexafluoride, "green salt"; and the Union Carbide and Chemical ElectroMetallurgical Division Works ("Electro-Met" for short) in Buffalo, New York, refined the "green salt" into uranium metal. There were also separate storage facilities in cleveland and in Middlesex County, New Jersey. In 1949 the AEC briefly considered consolidating these facilities after the security Division advised that Buffalo was too close to the northern border and the Atlantic ocean. The st. Louis area was better situated geographically but already had so many industrial plants that it was a "highly remunerative target" for a determined enemy attack. The AEC decided not to consolidate at that time, but when 
Mallinckrodt opened a uranium metal plant at its st. Louis works later that year, the commission decided to stop using Union Carbide's Buffalo plant.

In October 1950 the Production Division revived the idea of a single, consolidated processing facility as part of the general expansion of the production system authorized that month. The old Mallinckrodt facilities would be increasingly less efficient and less healthful for plant employees in the coming years of high-volume operation. Production Director williams authorized the New York Operations office to design a single plant for all phases of the processing work, to site it, and to have it in operation by January 1, 1953.

New York assigned the siting job to its engineering contractor, the Catalytic construction company. Together, they worked out preliminary criteria: a stream with a flow of 500 c.f.s. and a fast current to disperse the effluent; a square mile of relatively flat land (preferably with a government-owned facility already on it); 30,000 kilowatts of electrical power; and rail and highway connections. There should also be enough existing communities in the vicinity to support the facility, and the local population should include sufficient skilled construction workers and technically trained people to make it unnecessary to build a large housing development.

New York consulted the offices of the corps of Engineers within the geographical area that was then the "preferred" zone on Defense Department maps: the Ohio River Valley and the 
southeastern states. The corps suggested twenty sites, most of which had unused ordnance or chemical plants on them. But these were unsatisfactory; all except one were likely to be reactivated by the Army for the Korean War, and the one not liable to be reactivated--the Lake Ontario ordnance works which the AEC already owned--was outside the preferred zone.

The search was reopened. In the meantime, catalytic Construction's engineers learned of a new ion-exchange effluent decontamination process that allowed the water requirement to be cut in half. At the same time, the AEC's concern about housing and adequate skilled labor near sites was growing, making it evident to the company's officials that a location near a large city would be "extremely attractive." That eliminated the few remaining sites in the first group that the corps of Engineers had recommended.

A second approach, in January 1951, brought thirty-four sites into consideration. Most of these were recommended by the ten major railroads in the region, which catalytic construction had invited to assist in the search. In February the water requirement was reduced again, to $100 \mathrm{c.f.s.,} \mathrm{and} \mathrm{the} \mathrm{railroads}$ recommended an additional eight sites, two of which were at Fernald, ohio, near cincinnati. Catalytic construction engineers physically inspected most of the sites and eliminated all but four in the ohio-Indiana area. The company then applied a secondary set of criteria against these four, comparing freight rates and development and operating costs. "Fernald No. 2" and 
"Terre Haute, Indiana, No. 2" were judged to be the two best candidates, and the Catalytic construction company chose Fernald because its projected lower labor costs and local property values would more than offset the cheaper freight rates at Terre Haute.

The New York Operations office manager, W. E. Kelley, preferred Fernald for a number of "strategic" reasons relating to the rest of the AEC production system. Fernald, he said, was centrally located between the ore-delivery ports of New York and New orleans and the "AEC foci" at Hanford, Oak Ridge, Paducah, and Savannah River. The terrain of its square-mile area impressed him for security and safety reasons. Moreover, Fernald was close to a good labor force and service infrastructures in cincinnati. The city would also be attractive to the technical and supervisory personnel that would have to be drawn from other parts of the country.

2. HE Fabrication Facilities: PANTEX and Spoon River

a. PANTEX (1950)

Fabrication of high explosive (HE) components was done in a small shop at Los Alamos during the wartime Manhattan Project. The AEC in its early years entered a secret arrangement with the Army ordnance Bureau to operate a fabrication line at the Burlington Arsenal in Iowa (Project SUGAR). The contractor, Silas Mason Co., worked under contract to the Army. AEC personnel informally directed the contractor in the building, 
however, and the Army was satisfied to remain in administrative command.

In October 1950 the Division of Military Application (DMA) reported a need for an additional facility to match the expected output of the new reactors and gaseous diffusion plants that were being authorized that month. The DMA recommended that the Commission should open a new HE fabrication facility, away from the Burlington plant. The commission should acquire an unused ordnance plant, convert it to AEC specifications, and operate it independently through a direct contract with the contractor. The DMA staff reported that they had received tentative permission to use the PANTEX Ordnance works near Amarillo, Texas; they had inspected it and found that its old loading lines could be readily adapted to the AEC's purposes. PANTEX was remote enough so that only a few people would be disturbed by tests of explosives at the facility, yet it was close enough to Amarillo for commuting.

The Commissioners accepted the DMA's recommendation, and Chairman Dean wrote to the Chief of Army Ordnance to make the necessary transfer arrangements. Unfortunately, the chief of Army ordnance himself was not so accommodating as his staff had been earlier. In view of the Army's potential need for additional HE production during the korean conflict, he said, he could not permit the AEC to operate the plant independently. After a long and tedious correspondence, Dean capitulated and 
agreed that the contractor, Proctor and Gamble, would work at PANTEX under an Army contract.

b. The Spoon River Project (1951-1953)

The AEC planned to build a third $H E$ fabrication facility at spoon River, Illinois, but cancelled it before construction began. Still, it was sited, and the procedure illustrates how the AEC chose between two sites that were almost equally satisfactory for all of the criteria considered.

Project PLUM was conceived in November 1951 as the third of five HE fabrication facilities that the DMA envisioned would be necessary to match projected reactor output and military requirements after 1955. Originally, DMA assumed that Army ordnance officers would administer PLUM as they did at PANTEX and Burlington, but the AEC Commissioners preferred to operate it independent1y, through the Santa Fe operations office (SFOO). The DMA thereupon sent the chosen contractor, the Fluor company, a set of siting criteria and invited the company to conduct a survey of the southern and central regions of the country. The DMA preferred acquiring a government-owned site. Fluor recommended two, one in Mississippi and another in oklahoma, but the DMA rejected them as too isolated. The DMA meanwhile asked the three armed services if they had any unused plants, and the Army suggested two: Camp Ellis near spoon River, Illinois, and the Weldon spring ordnance Works in Missouri. Fluor inspected them and reported that they would both be satisfactory, but they 
were also both encumbered with third-party tenant arrangements: Camp Ellis had Army and Air National Guard facilities, and Weldon Springs had been leased to the University of Missouri. The company requested additional criteria.

The DMA instructed Fluor to make a comparative study of the costs of adapting and operating the ordnance plants at the two sites. Once again Fluor found that they were nearly equal: at Weldon springs the company would have to remodel the existing linear layout of the loading line into a contour arrangement; this would cost as much as reopening either of the two lines at Camp Ellis. The slightly cheaper fuel costs at Camp Ellis were mostly offset by higher electric power costs. Projected labor costs differed only slightly. If Weldon springs was selected, the AEC would have to close a state highway running through the site and construct an alternate route through a state wildife preserve, all of which would entail fresh problems. If Camp Ellis was chosen, however, the labor force would be drawn from a much wider area and housed at a greater distance from the site. Fluor preferred Camp Ellis because one of its lines would be the easiest to reconfigure for AEC work.

In January 1953 the AEC Commissioners themselves decided the contest by seizing upon the one issue that mattered most to them after the difficulties Chaiman Dean had experienced in acquiring PANTEX: the Army ordnance office had informed the DMA that Weldon springs was the more likely of the two plants to be needed in the event of a national mobilization. The DMA recommended 
Camp ElIis because the AEC would have greater freedom of action there. Dean added that the cost of reconverting the loading lines to the Army's specifications in the event of a mobilization would be much greater than the actual savings gained by converting these ordnance plants, so the best course would be to choose and convert the one least likely to be lost later. The other Commissioners concurred. Camp Ellis was selected.

Less than a year later, even before construction plans were finished, the DMA recommended closing Project PLUM. The military requirements for fission weapons were less than expected, the DMA explained; more than two $\mathrm{HE}$ plants would not be needed after all. Plainly irritated, the commissioners demanded a thorough study of costs and needs to assure themselves that they would not have to reopen PIUM.

3. Rocky Flats Fabrication Facility (1951)

The siting of Project APPLE, the "alternate fabrication facility" for Los Alamos, was done by the santa Fe operations office and its chosen contractor for the facility, Dow Chemical, in early 1951. Dow was instructed to choose a general area that would be accessible to Los Alamos, inside the "strategic invulnerability" zone designated by the Defense Department, and isolated enough not to require displacing many people but with a supporting population in the vicinity. These considerations were common to many of the AEC's siting decisions at that time. For this facility, however, there was also a unique requirement: a 
dry, moderate climate. The AEC needed to save several million dollars in constructing and operating it 19 million dollars less than the $A E C$ had requested for it had finally been budgeted), and the largest cost-cutting measure would be to substitute a natural evaporative cooling system instead of refrigeration.

The Santa Fe office also decided that "attractive environs" were desirable: skilled personnel would have to be compensated for the extremely hazardous work by offering them beautiful scenery and extraordinarily good outdoor recreation possibilities.

of twenty-one areas that were suggested, Dow and the santa Fe office agreed that only the Denver area satisfied all these criteria. It was the only one that had a climate dry enough to make evaporative air conditioning feasible, and its mountain setting was both beautiful and promising for outdoor recreation. Denver was a tourist center with many transient housing facilities that could absorb the construction crews as well as the operating personnel. This was a strong point in its favor following the congressional hearings in February 1951 about the grave housing problems at Paducah and Savannah River.

The Denver area had another plus in the eyes of the planners in santa $\mathrm{Fe}$ : many of the machinists, subprofessional, and clerical personnel at the Los Alamos laboratory came from Denver, and it would probably not be difficult to attract them to work at the new facility. 
The Santa Fe operations office inspected eight other areas, which confirmed their original judgment that the Denver area convincingly outshone the competition.

Once Denver had been chosen as a general area, the Santa Fe Operations office and Dow representatives visited seven specific locations near the city. To choose among these potential sites, they applied a secondary set of criteria. For the sake of safety they wanted isolation, away from the city itself, its airport, and residential areas. Two sites satisfied this requirement: Rocky Flats and a site to the north of the Rocky Mountain Arsenal. But at the latter site the power transmission lines would have to be shared with the Arsenal, and in the event of a national emergency the AEC facility might have to limit operations because of the limited capacity of these transmission lines to provide current to both facilities. The transmission Iines which passed near the Rocky Flats site would serve no other major plant. Finally, the survey team observed that the soil around the Arsenal was loess, which would become blown dust in a windstorm, creating an extra burden on air-filtration systems. The Dow representatives concurred with the santa Fe operations office: Rocky flats was the preferred site.

\section{Initiator Production Facilities}

a. Miamisburg and Marion, Ohio

The Dayton Project, of which the Mound Laboratory became the main facility, furnished initiators for nuclear weapons under the 
Manhattan Engineer District (MED). Hastily established in three Dayton locations under wartime emergency conditions in 1943, the Dayton facilities were an early target for consolidation and rebuilding.

The decision to construct a plant in Miamisburg, ohio, grew out of increased needs for polonium used in initiators to supply weapons built for the MED. When the MED determined in 1945 that leased facilities in Dayton and oakwood, ohio, would not be satisfactory for the increased size and responsibilities of the expanded program, Army efforts focused on finding a new site.

Toward the latter part of 1945, the MED began to consider plans for a new polonium production plant to supersede the plants in Dayton.

originally, the X-10 Advisory Committee, meeting in November 1945, had agreed that a new plant would be built at the clinton Engineer Works at oak Ridge. However, the reluctance of Dayton personnel to move to Tennessee and concern about polonium contamination near the oak Ridge plutonium plant caused the committee to seek a suitable site elsewhere.

clearly, the desire to keep the scientific staff and nontechnical personnel played a critical part in the final selection. So, too, did the fact that General Kenneth D. Nichols favored locating the new plant near Daytor. Later, an additional requirement that the plant should be built underground for defense purposes led to the selection of the Miamisburg site. By July 1946, Monsanto, which operated the Dayton facility, had 
designed a new underground facility. The company chose an 170acre site for it, about fifteen miles southwest of Dayton and one mile from Miamisburg, ohio. Preliminary site work began at the end of July 1946. By January 1949 all weapon initiator work was transferred to the new facility at Miamisburg and both sites in Dayton were shut down.

In early 1947, as work on the Miamisburg facility proceeded in secret, the commission decided to enhance the security of its polonium and initiator supply by opening a second production line, Unit VI, away from Dayton. The lack of an alternate site for polonium and initiator production was a critical vulnerability of the weapons program. The short half-life of polonium precluded stockpiling it, but projected military requirements for polonium were expected to outstrip production capacity by 1950 .

The extreme secrecy of the entire Dayton operation dictated the choice of Monsanto as the Unit VI contractor. This, plus the requirement that atomic production facilities be dispersed, determined the criteria for the site. The second production line should be far enough away from the Miamisburg site to satisfy the dispersion requirement, but close enough to permit Monsanto to coordinate operation of the two facilities. The ideal site would preferably be a site already owned by the government.

AEC Director of Production Walter J. williams directed the search. The survey was conducted by the oak Ridge and Dayton offices, with Monsanto personnel participating. On November 7 , 
1947, Williams reported to the AEC that the only site which satisfied the requirements was the Jefferson Proving Ground near Madison, Indiana, approximately 100 miles from Dayton. The bombing range there had been designated surplus and had been maintained on a standby basis by the Army. The Army had already solicited bids from the public for some of the buildings on the site but as of october 1947 had not made any definite commitments. Joint occupancy of the site with the Army would relieve the AEC of the burden of constructing its own support facilities. williams reported that the Jefferson proving Ground had certain disadvantages. From the standpoint of safety, it was undesirable to locate an initiator facility so close to a bombing range. Another minus was the shortage of housing in the area, but Williams rationalized this away by saying that the same problem would arise "with almost any other site that he might select."

The Commissioners approved the site on November 14, 1947.

In negotiations with the office of the chief of Army Ordnance, Williams discovered that the Army planned to maintain the Madison site on standby basis indefinitely. In an emergency, the Army's testing of high-calibre ordnance would interfere with instrumentation at the initiator facility.

Williams reopened the search for a site for Unit VI. He asked the oak Ridge manager to search for alternate locations which met the twin criteria of dispersion with proximity to Monsanto's other facilities in the area. Again, preferably, the 
site should be on government-owned land. The ideal site should be "reasonably close" to a community large enough to house operating personnel and, to reduce costs, should have utilities and usable structures already in place.

In January 1948 williams reported the results of the new survey. The wabash River ordnance works at Apio, Ohio, had no usable structures and was too remote from existing communities. A power plant on the wabash River was too large to permit economical operation of the facility, and both sites were too far away from Miamisburg to permit an efficiently coordinated operation.

The scioto ordnance Works at Marion, Ohio, was the most promising candidate. The War Assets Administration had scheduled it for disposal, so there should not be any difficulty arranging for it to be transferred to the AEC. Its existing structures would serve as a basis for construction. The nearby town of Marion could easily house the expected construction and operating personnel. Scioto, only 110 miles from Miamisburg, satisfied the twin criteria of dispersion and proximity.

The AEC approved the scioto site on January 21, 1948. In 1953 the AEC determined that it no longer needed the scioto laboratory and it was closed down.

b. The Pinellas Peninsula plant (1955-1956)

In contrast to Mound, the pinellas facility site selection was not complicated by requirements of defensibility, dispersion, 
or proximity to other facilities. The super-urgent need for a specific type of initiator that the General Electric company had under development in late 1955 made time the overwhelming "strategic" consideration for siting the production plant. The DMA recommended only two criteria for the general area where the plant would be located: "a good labor supply and the best possible climate for uninterrupted and most rapid construction." speedy recruitment of skilled workers and technical personnel made an attractive environment desirable. Florida satisfied these requirements, and no objections were raised to General Electric's decision to locate the plant on the Pinellas peninsula on Tampa Bay. 
SOURCES FOR CHAPTER IV

Fernald Feed Materials Production Center (1950-1951)

AEC 194, 194/1. Adequacy of Feed Material Facilities, March 7, 1949.

AEC 194/2. Elimination of Feed Production at Linde and Electro Met, June 17, 1949.

AEC 421. Site Selection for Feed Materials Production Center, March 27, 1951.

Minutes of the 542 nd AEC Meeting, March 28, 1951.

HE Fabrication Facilities: PANTEX and spoon River

PANTEX

AEC 382. Selection of a Site and Method of Operation for New $H E$ Fabricating Facility, November 28, 1950.

AEC 382/2. Selection of a site and Method of Operation for New HE Fabricating Facility, February 21, 1951.

AEC 382/3. Method of operation of New HE Fabrication Facility, March 13, 1951.

AEC 382/4. Operation of HE Fabrication Plants, October 16, 1952.

Minutes of the 482nd AEC Meeting, October 12, 1950.

Minutes of the 495 th AEC Meeting, November 20, 1950.

Spoon River

AEC 595. Site Selection for Project PLUM, October 30, 1952.

AEC 595/1. Justification for a New HE Facility and selection of a Site Thereof, December 19, 1952.

AEC 595/2. Location of Project PLUM, December 18, 1952.

AEC 595/7. Termination of AEC Interest in spoon River Plant, April 8, 1954.

Minutes of the 789th AEC Meeting, December 17, 1952. 
Minutes of the 807th AEC Meeting, January 22, 1953.

Minutes of the 938 th AEC Meeting, November 3, 1953.

Rocky Flats Fabrication Facility (1951)

AEC 394. Selection of operating contractor for Project APPLE, January 8,1951 .

AEC 394/1. Selection of operating contractor for Project APPLE, January 22 , 1951.

AEC 394/2. Scope of Project APPIE, January 24, 1951.

AEC 394/3. Decision on AEC 394/2, Scope of Project APPLE, January 29 , 1951 .

AEC 394/4. Selection of a site for Project APPLE, March 20, 1951 .

AEC 394/5. Decision on AEC 394/4, selection of a site for Project APPLE, March 27, 1951.

Initiator Production Facilities: Mound and Pinellas

Mound

Manhattan District History. Book VIII, Los Alamos Project (Y): Vol. 3, Auxiliary Activities; Chapter 4, Dayton Project.

AEC 15. Site Selection - Monsanto Unit VI, January 19, 1948.

AEC 15/1. Site Selection - Monsanto Unit VI - Letter From the Military Liaison Committee, March 22, 1948.

Minutes of the 143rd AEC Meeting, January 21, 1948.

USDOE, RG 326, AEC, Operations 9/14/53, secretaries File, PBL\&L $7,6 / 23 / 55$ and $11 / 24 / 54$, Folder 635.51 .

Pinellas

AEC 127/13. Acquisition of Florida Manufacturing Plant, December 14 , 1956 .

AEC 127/15. Operation of the Pinellas Plant at clearwater, Florida, January 7 , 1958. 
"Effect of External Initiators on System Planning," memorandum of $K$. Hertford, Manager of Albuquerque Operations office, AEC, to Brig. Gen. A. Starbird, Director of Military Application, $A E C$, June 14, 1956.

Minutes of the 1255th AEC Meeting, December 18, 1956. 


\section{APPENDIX A}

\section{DATA ABOUT SELECTED PRODUCTION FACILITY SITES}


NAME

LOCATION

SIZE

DATE ACQUIRED

BY AEC

ORIGINAL LANDLORD

(if not MED)

ORIGINAL USE

CONTRACTORS

WATER SUPPLY

GEOGRAPHIC

CONDITIONS

POWER SUPPLY

LABOR RESOURCES

OTHER SITES

CONSIDERED
Y-12, Oak Ridge, originally known as clinton Engineer Works

Roane and Anderson counties, Tennessee.

Currently 3rd Congressional District. In

1942, 2nd Congressional District.

$93 \mathrm{sq.} \mathrm{mi.} \mathrm{(59,000} \mathrm{acres);} \mathrm{rectangular} \mathrm{area}$

$16 \mathrm{mi}$. $x 7 \mathrm{mi}$, bounded on three sides by

Clinch River and Black Oak Ridge.

1942 by MED, 1946 by AEC.

Before acquisition by MED, the land was held by multiple private owners.

Agricultural

Tennessee Eastman Corp., 1943-1947

Carbide and Carbon Chemicals Corp., 19471984

Martin Marietta Energy Systems, Inc., 1984

Clinch River - 370,000 gallons/minute.

Flat areas divided by ridges (200-300 ft). Firm substrata.

TVA power with a $154 \mathrm{KV}$ line nearby.

Local population unskilled. Construction and skilled workers available in nearby Knoxville and cookville.

(1) Spokane, Washington

(2) Chicago

(3) Mt. Shasta area, California 
NAME

LOCATION

SIZE

DATE ACQUIRED

BY AEC

ORIGINAL LANDLORD (if not MED)

ORIGINAL USE

CONTRACTORS

WATER SUPPLY

GEOGRAPHIC CONDITIONS

POWER SUPPLY

LABOR RESOURCES

OTHER SITES CONSIDERED
Hanford Engineer Works

Benton County (also parts of Yakima, Grant, Adams, and Franklin counties) in southeastern Washington; 4 th Congressional District.

$670 \mathrm{sq} . \mathrm{mi}$. Roughly circular area

$37 \mathrm{mi}$. (N-S) $\times 26 \mathrm{mi}$. (E-W).

December 31, 1946. Truman's Executive order No. 9816 transferred all MED property and materials to the newly formed AEC.

One-third of land government-owned $(71,000$ acres federal, 45,000 acres state, 41,000 acres counties). Remainder private.

$88 \%$ sagebrush sheep range, $11 \%$ irrigable farm land, including orchards; most low productivity.

Dupont (1942-46)

General Electric (1946-Present)

Columbia River - 25,000 gallons/minute.

Sagebrush provided isolation; inland to provide against air attack. Flat to slightly rolling terrain. Bounded by Yakima and Columbia rivers and $3500 \mathrm{ft}$. steep ridge line. Ground and subsurface of sand and gravel over shale and sandstone over basalt could support heavy loads.

Two 230-kilovolt lines at each of Bonneville and Grand Coulee generating plants connected at Midway station in northwest corner of site. At least 100,000 kilowatts of power would be needed.

Town of Yakima located 140 miles to the west with population of 30,000 . Local population plus thousands recruited throughout the United States.

(1) Grand Coulee area, Washington

(2) Pit River, near Shasta Dam, California

(3) California border near Blythe-Needles, needed additional generating plants at Hoover Dam

(4) Deschutes River, Oregon 
NAME

LOCATION

SIZE

DATE ACQUIRED

BY AEC

ORIGINAL LANDLORD

(if not MED)

ORIGINAL USE

CONTRACTORS

WATER SUPPLY

GEOGRAPHIC

CONDITIONS

POWER SUPPLY

IABOR RESOURCES

OTHER SITES

CONSIDERED
Mound Plant. (1) Dayton Project (Unit 3 and Unit 4): (2) Mound (Unit 5), 1946; Mound Laboratory, 1948

Unit 3 - Dayton, ohio; Unit 4 - Oakwood, Ohio; Unit 5 - Miamisburg, Ohio

Unit $3-2.3$ acres; Unit $4-3.88$ acres; Unit 5 - 169.7 acres.

I946 from MED; Units 3 and 4 shut down in 1949. Mound in 1946; Units 3 and 4 acquired from MED in 1946.

Unit 3 - Dayton Board of Education, 1943-46; Unit 4 - Talbott Realty Co., 1944-?; Unit 5 Private owners, 1946

Land had been donated to state as park land.

Monsanto, 1943-present.

Information unavailable.

Appropriate for underground construction; isolated from public by Indian burial mound and state park land.

Information unavailable.

Skilled labor from Dayton project readily available.

Oak Ridge; other areas around Dayton. 
NAME

LOCATION

SIZE

DATE ACQUIRED

BY AEC

ORIGINAL LANDLORD

(if not MED)

ORIGINAL USE

CONTRACTORS

WATER SUPPIY

GEOGRAPHIC

CONDITIONS

POWER SUPPLY

LABOR RESOURCES

OTHER SITES

CONSIDERED
Kansas City Facility, AEC Project Royal

Kansas City, Missouri; Jackson County.

1 million sq. ft. in $1948 ; 2.2$ million sq. ft. in 1965; currently 122 acres.

December 31,1948

i942 - Pratt \& Whitney

1945 - Declared surplus and taken over by war Assessments Board

1948 - Transferred to control of U.S. Navy

1942 - Aircraft engine production plant for World War II effort. No description of Westinghouse activities found.

Bendix Corporation since 1948 .

Information unavailable.

Information unavailable.

Information unavailable.

Population of Kansas City adequate to support the operation.

None recorded. 
NAME

LOCATION

SIZE

DATE ACQUIRED

BY AEC

ORIGINAL LANDLORD (if not MED)

ORIGINAL USE

CONTRACTORS

WATER SUPPLY

GEOGRAPHIC CONDITIONS

POWER SUPPLY

LABOR RESOURCES

OTHER SITES CONSIDERED
Pocatello, Idaho; also known as Arco

Butte, Bingham, and Jefferson counties; 2 nd Congressional District.

687 sq. mi. $(440,000$ acres $)$.

1950

170,000 acres controlled by U.S. NavY Bureau of Ordnance; 11,348 acres controlled by private landowners; 14,717 controlled by state.

170,000 acres were used for testing naval guns; 248,000 acres were public lands; 11,348 acres were private lands; 14,717 were stateowned school lands.

Phillips Petroleum since 1951.

Large reserve of ground water contained in lava flows obtainable by well field situated on the snake River plain.

Mostly flat terrain; vegetation ranges from sparse to heavy.

Inadequate supply from local power company transmission lines; necessary to expand local power sources.

Remote; availability of local labor was not considered in the selection.

(I) Fort Peck, Montana

(2) Kingsley Dam area, Nebraska

(3) Oahe, North Dakota

(4) Klamath Falls, Oregon

(5) Wilmington, North Carolina 
NAME

LOCATION

SIZE

DATE ACQUIRED

BY AEC

ORIGINAL LANDLORD (if not MED)

ORIGINAL USE

CONTRACTORS

WATER SUPPLY

GEOGRAPHIC

CONDITIONS

POWER SUPPLY

LABOR RESOURCES

OTHER SITES CONSIDERED
Paducah Plant

Kentucky ordnance Works, $16 \mathrm{mi}$. west of Paducah, Kentucky, on the south bank of the Ohio River.

Approximately 5000 acres.

1950

1,400 acres owned by U.S. Army. Most of remaining 3,600 acres had been recently sold off by the government, subject to repurchase.

Site of the Kentucky ordnance Works.

Carbide and Carbon Chemicals, Division of Union Carbide and Carbon Corp, 1950-

Ohio River.

Flat terrain with soil having a relatively high bearing capacity; under cultivation at time of acquisition.

TVA; local electric power companies; cheap supply of coal from western Kentucky coal fields. Necessary to construct generating plant near site.

Population of Paducah $(40,000)$ was large enough to support the construction and operation program. Some skilled craftsmen were recruited elsewhere.

(1) Louisiana ordnance Works, Shreveport

(2) Longhorn ordnance Works, Marshall, Texas 
NAME

LOCATION

SIZE

DATE ACQUIRED

BY AEC

ORIGINAL LANDLORD (if not $M E D$ )

ORIGINAL USE

CONTRACTORS

WATER SUPPIY

GEOGRAPHIC CONDITIONS

POWER SUPPIY

IABOR RESOURCES

OTHER SITES CONSIDERED

\section{Savannah River}

Aiken and Barnwell counties, South Carolina, 3 rd Congressional District. $15 \mathrm{mi}$. south of Aiken, SC, $20 \mathrm{mi}$. southeast of Augusta, Georgia.

$375 \mathrm{sq} . \mathrm{mi}$.

$1950-1951$

Mixture of state, county, and small individual holdings.

Pasturage and crop cultivation (70\%); timber stands, mainly hardwood (20\%); and residential and waste (10\%).

DuPont, June 1950-

Savannah River - I,040 cu. ft./sec. daily average flow; $69^{\circ} \mathrm{F}$ annual mean temperature; virtually mineral free; located $9.5 \mathrm{mi}$. from reactor area.

Rolling and table lands; sandy soil.

Local electric utility $(125,000$ kilowatts were added by the utility).

Aiken, population $25,000,15 \mathrm{mi}$. from site. Additional 25,000 people spread within 15mi. radius of site.

(1) Site on the Red River $15 \mathrm{mi}$. northwest of Bonham, Texas

(2) Illinois site on wabash River $21 \mathrm{mi}$. southwest of Terre Haute, Indiana

(3) Wisconsin site on Lake Superior $29 \mathrm{mi}$. east of Duluth, Minnesota 
NAME

LOCATION

SIZE

DATE ACQUIRED

BY AEC

ORIGINAL LANDLORD

(if not MED)

ORIGINAL USE

CONTRACTORS

WATER SUPPLY

GEOGRAPHIC

CONDITIONS

POWER SUPPLY

LABOR RESOURCES

OTHER SITES

CONSIDERED
Feed Materials Production Center, Fernald, Ohio

Fernald station, Ohio. $19 \mathrm{mi}$. northwest of Cincinnati; Hamilton County; 2nd Congressional District.

1200 acres

March 1951

Multiple private landowners.

Agricultural.

National Lead of Ohio, 1951-1985

Westinghouse Corporation, 1985-Present

Miami River flow rate was in excess of 100 cu. ft./sec.

Flat, well-drained land.

30,000 kilowatts available.

Nearby Cincinnati provided labor and housing.

Terre Haute, Indiana

Mooresville, Indiana

Hamilton, ohio 
NAME

LOCATION

SIZE

DATE ACQUIRED

BY AEC

ORIGINAL LANDLORD (if not MED)

ORIGINAL USE

CONTRACTORS

WATER SUPPLY

GEOGRAPHIC CONDITIONS

POWER SUPPLY

IABOR RESOURCES

OTHER SITES

CONSIDERED
PANTEX

Amarillo County, 13th Congressional District; $23 \mathrm{mi}$. northeast of Amarillo, Texas.

$11 \mathrm{sq} . \mathrm{mi}$. when acquired in $1951 ; 16 \mathrm{sq} . \mathrm{mi}$. in 1955; and $14.2 \mathrm{sq}$. $\mathrm{mi}$. in 1971 .

1951

Texas Technological College and U.S. Army (in "dormant estate" after sale to college in 1949).

Unused manufacturing plant on the grounds of an experimental farm.

Proctor and Gamble, 1951-1956

Mason and Hanger Silas Mason Co., Inc. 1956-

Information unavailable.

Relatively isolated; permitted test firing of explosives without complaint.

Information unavailable.

Labor force and existing community facilities at Amarilio were considered adequate. They particularly satisfied the AEC's wish not to build and manage such facilities.

None recorded. 
NAME

LOCATION

SIZE

DATE ACQUIRED

BY AEC

ORIGINAL IAANDLORD

(if not MED)

ORIGINAL USE

CONTRACTORS

WATER SUPPLY

GEOGRAPHIC

CONDITIONS

POWER SUPPIY

LABOR RESOURCES

OTHER SITES

CONSIDERED
Rocky Flats, Colorado

Jefferson County, colorado - $17 \mathrm{mi}$. northwest of the center of Denver; 2 nd and 6 th Congressional Districts (current).

4 sq. mi. $(2,587.56$ acres $)$ originally acquired. present size $10.32 \mathrm{sq}$. $\mathrm{mi}$. $(6,606$ acres $)$.

1951

Privately owned by six landowners.

Unoccupied except for cattle grazing.

Dow Chemical Company, 1952-1975

Rockwell International, 1975-

Available via 4-1/2 mi. extension from Ralston reservoir; needed treatment.

Located on isolated Mesa 1,000 feet above Denver in the foothills of the Rocky Mountains.

Three 115-kilovolt power lines within $2 \mathrm{mi}$. of the site. Gas line $4 \mathrm{mi}$. offsite.

Nearby Denver and Boulder considered advantageous for housing and labor supply.

Area north of Rocky Mountain Arsenal, near Denver. 
NAME

LOCATION

SIZE

DATE ACQUIRED

BY AEC

ORIGINAL IANDLORD

(if not MED)

ORIGINAL USE

CONTRACTORS

WATER SUPPLY

GEOGRAPHIC CONDITIONS

POWER SUPPLY

LABOR RESOURCES

OTHER SITES

CONSIDERED
Portsmouth

Pike County, Ohio; Scioto and seal Townships $20 \mathrm{mi}$. north of Portsmouth.

64,000 acres originally acquired. Reduced to 3,700 acres in February 1953.

August 1952

Multiple private landowners.

Agricultural.

Goodyear Atomic Corp., a subsidiary of

Goodyear Tire and Rubber Company, 1952-

Wells dug near Sciota River, pumped by electric power through a 48" water pipeline.

Gently rolling glacial plain; subsoil chiefly plastic clay; natural surface drainage listed as fair; no subsurface drainage was required.

The AEC contracted with the onio valley Electric Corp., a group of 15 private power companies, to supply the $1,800,000 \mathrm{kw}$ required.

The local area was considered only fair in terms of labor supply. The area within 40 $\mathrm{mi}$. of the site had a population of 423,000 which included Portsmouth $(37,000)$ and chillicothe $(20,000)$.

Louisville, Kentucky

Cincinnati, ohio 


\begin{tabular}{|c|c|}
\hline NAME & Pinelias Peninsula Plant \\
\hline LOCATION & $\begin{array}{l}\text { Pinellas County, Clearwater, Florida; 8th } \\
\text { Congressional District. }\end{array}$ \\
\hline SIZE & $0.14 \mathrm{sq} . \mathrm{mi}$. (90 acres). \\
\hline $\begin{array}{l}\text { DATE ACQUIRED } \\
\text { BY AEC }\end{array}$ & June 1957 \\
\hline $\begin{array}{l}\text { ORIGINAL LANDLORD } \\
\text { (if nOt MED) }\end{array}$ & General Electric Corporation \\
\hline ORIGINAL USE & Recently constructed manufacturing plant. \\
\hline CONTRACTORS & $\begin{array}{l}\text { General Electric Corp., X-Ray Division, since } \\
1957 .\end{array}$ \\
\hline WATER SUPPLY & Not a criterion in the selection. \\
\hline $\begin{array}{l}\text { GEOGRAPHIC } \\
\text { CONDITIONS }\end{array}$ & $\begin{array}{l}\text { Excellent. Year-round fair weather was the } \\
\text { main factor determining the choice of } \\
\text { Florida. }\end{array}$ \\
\hline POWER SUPPIY & Adequate \\
\hline LABOR RESOURCES & Adequate \\
\hline $\begin{array}{l}\text { OTHER SITES } \\
\text { CONSIDERED }\end{array}$ & None \\
\hline
\end{tabular}


15. Comfar: jon of the Ft. Peck and Pocatello S1tes

The two most outstanding sites, Ft. Peck, Montani and Pocatel10, Idaho, have been the subjects of a comparative survey carried out by the architectural and.ene1reerlne fira of Srith, Hinchman \& Grylls, Inc., and speclallsts employed by ther.. The comprehensive findings of this firm are 1ncluded in a report*frev1ousiy circulated to the Comrission. These findings have bet supported by the flridings of the Reactor Safeguard Committee, thuse Federal Agencies given above and also the Departmert of Comaterce Coast and Geodet1c Survey; the Department of Interior Power Division Bureau of Reclamation, and Borrevilie Fower Administration and others. A summary of the findings of Srith, Hinchman \& Grylle $1 \mathrm{~s}$ given below:

\section{Character1st1c}

Ft. Peck

$\underline{\text { PCCEtEIIO }}$

1. Isolation

Preferred

2. Security problems

Freferrez

3. cilmate

Preferred

4. Geology

Prererred

5. Drainage

Preferred

6. Water supply system

Equal

Equal

7. Avallab1l1ty of maspower

Preferred

8. Avaliab111ty of materlals

Preferred

9. Population and social-economic factors

Freferred

10. Ava1lab1lity of lard

Eque]

Eque]

11. Corstruction and operationai costs

Preferred

12. Transportation

Preferred

13. Electric Fower

Prefennec

14. Fuel avallability and costs Preferreo Or the basis of this analysis, Smith, Hinchmen \& Grylls, Inc, has concluded that the site at Pocetello is preferable and has rectrmended that the new racliity te losated in that aree.

* The Smith, Hirohmen, Gryils' refort is on irterin refort. i setailed $r \in p o r t$ amplifyine but rot cherelre the fincires is $1 \mathrm{r}$ prefaration and will be availatle ty $3 / 15 / 49$.

Source: AEC 142/3, "Site Selection for Reactor Testing Station," February 15, 1949. 


\section{APPENDIX B}

Idaho Reactor Testing Station (1949)

Facsimile of the Engineering Division's summary "Comparison of the Ft. Peck and Pocatello sites" (AEC 142/3, February 15, 1949) 


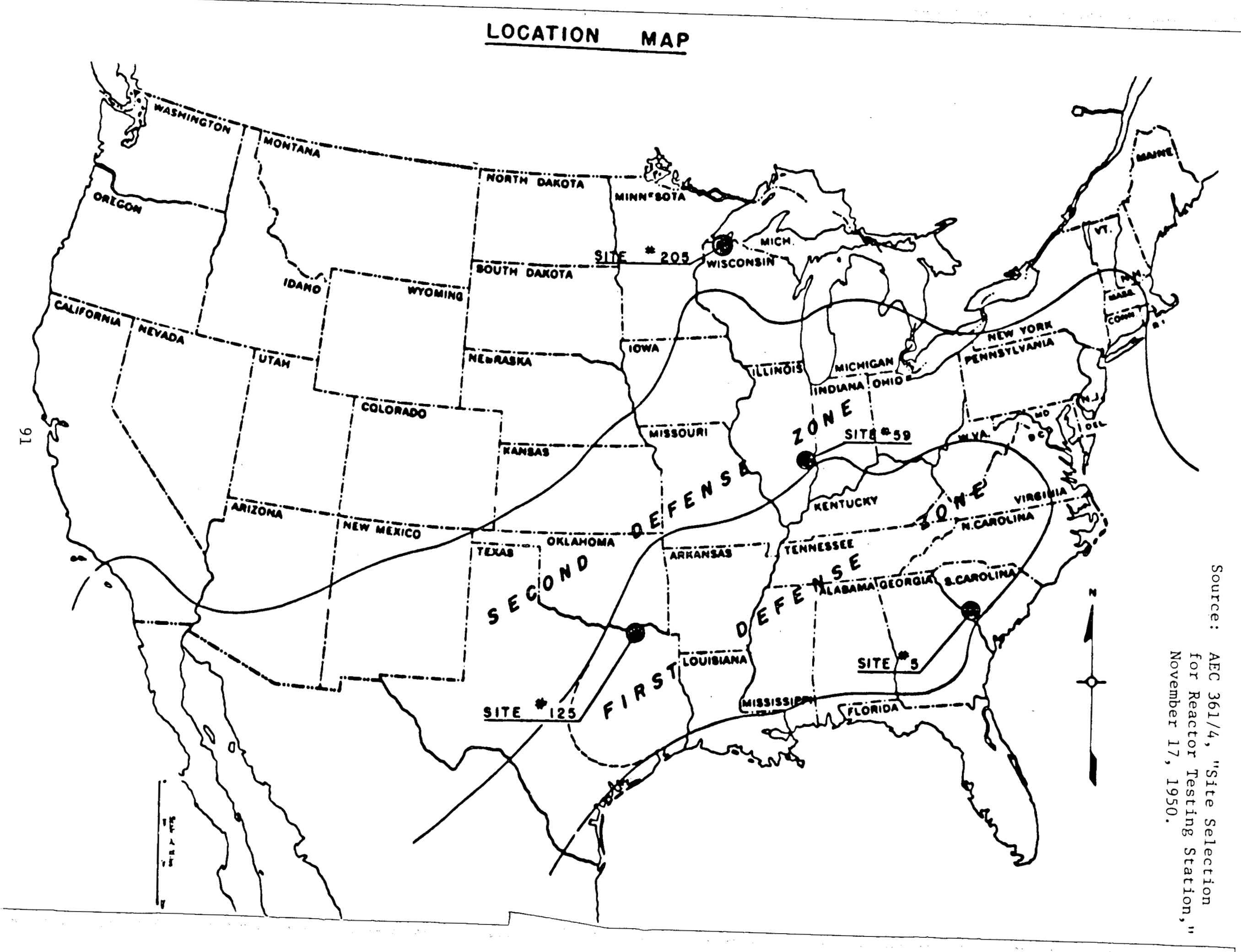




\section{APPENDIX C}

SAVANNAH RIVER SITE SELECTION, 1950: Defense Department Map of Preferred Defense Zones, with the four final candidate sites indicated by black circles. 


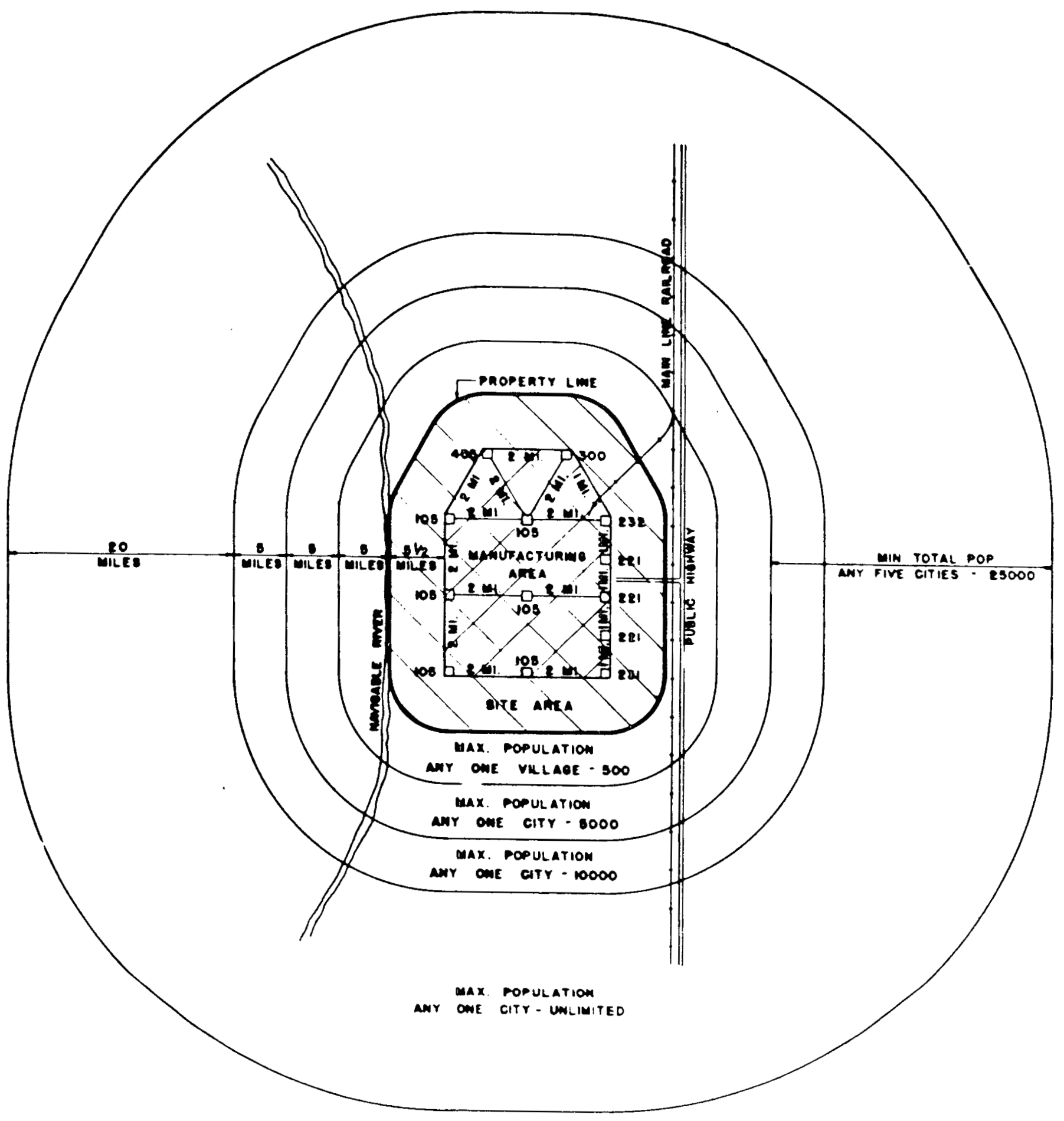

mers.

mot to sCale.
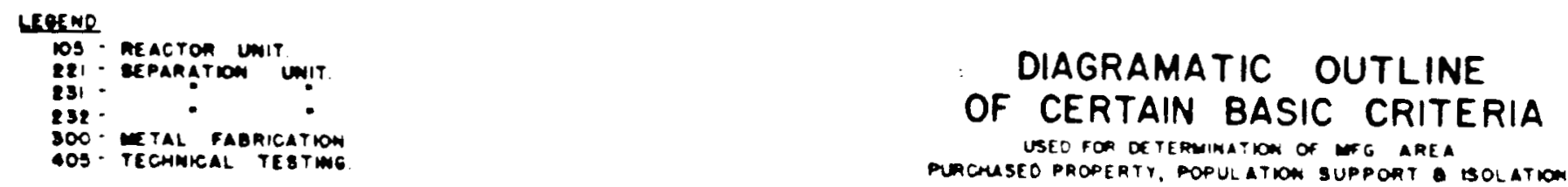

Source: AEC 361/4, "Site Selection for Reactor Testins Station." 


\section{APPENDIX D}

SAVANNAH RIVER SITE SELECTION, 1950: Schematic Diagram of Preliminary Technical, safety, and Population Criteria. 